\title{
AS COSMOVISÕES DOS POVOS INDIGENAS KICHWAS WAORANIS, BUEN VIVIR E A INICIATIVA YASUNI-ITT
}

\author{
JANETE SCHUBERT ${ }^{1}$ \\ FLACSO, EQUADOR \\ https://orcid.org/0000-0003-1227-9523
}

\begin{abstract}
RESUMO: Neste artigo discutimos as cosmovisões dos povos indigenas das etnias Kichwas e Waoranis com relação à proposta da Iniciativa Yasuni-ITT no Equador. Adotamos uma metodologia de cunho qualitativo para esta pesquisa, a qual foi realizada na Região Amazônica Equatoriana (RAE), em 2017. Nosso percurso empírico-analítico visou mapear e compreender a(s) perspectiva(s) dos povos indigenas sobre a proposta da Iniciativa Yasuni-ITT e da exploração de petróleo nos territórios de possessão ancestral. Como também, discutimos o turismo comunitário como uma das alternativas de desenvolvimento voltado ao Sumak Kawsay/Buen Vivir e ecoamos alguns processos de resistência contra o extrativismo desde as comunidades indigenas. O campo nos propiciou perceber como se manifestam no mundo vivido as cosmovisões destes povos, sobretudo no que tange à forma de se relacionar com o território e com outras formas de vida. Recordemos que para estas cosmovisões um aspecto importante é o relacional, sendo assim não existe a ideia de indivíduo, porque somos família, somos comunidade, não existe um eu separado dos outros, por isso intersomos: eu sou porque tu és; que também é a filosofia Ubuntu na África.
\end{abstract}

PALAVRAS-CHAVE: Iniciativa Yasuni-ITT, Povos indigenas, Extrativismo, Buen Vivir, Decolonialidade.

ABSTRACT: In this article, we discuss the cosmovisions of indigenous peoples of the Kichwa and Waorani ethnic groups regarding the proposal of the Yasuni-ITT Initiative in Ecuador. We adopted a qualitative methodology for this research, which was carried out in the Ecuadorian Amazon Region (RAE) in 2017. Our empirical-analytical journey aimed to map and understand the perspective(s) of the indigenous peoples with whom we lived on about the proposal of the Yasuni-ITT Initiative and about the oil exploration in their ancestral possession territories. As well, we discussed community tourism as one of the development alternatives to the Sumak Kawsay/Buen Vivir and we reverberate some resistance processes made by indigenous communities against extractivism. The field work allowed us to understand how the cosmovisions of these peoples are manifested in the lived world, especially when it comes to their way of relating to the territory and to other forms of life. For these cosmovisions, an important aspect is the relational one, therefore there is no idea of individual, we are family, we are community, there is no self separated from others: I am because you are; which is also the Ubuntu philosophy in Africa.

KEYWORDS: Yasuni-ITT Initiative, Indigenous peoples, Extractivism, Buen Vivir, Decoloniality.

\footnotetext{
${ }^{1}$ Doutora em Sociologia pela Universidade Federal do Rio Grande do Sul (UFRGS). Pesquisadora associada a Faculdade Latino-americana de Ciências Sociais (FLACSO). E-mail: killari.jschubert@gmail.com.
} 


\section{Os direitos da natureza, Sumak Kawsay/Buen Vivir e as políticas extrativistas}

O Sumak Kawsay/Buen Vivir e o Suma Quamaña/Vivir Bien ganham notoriedade ${ }^{2}$ ao se materializar nas Constituições ${ }^{3}$ do Equador, de 2008, e da Bolívia, de 2009. Os presidentes Rafael Correa e Evo Morales, eleitos em 2006 e 2005, respectivamente, incorporaram alguns aspectos das cosmovisões dos povos originários (GUDYNAS, 2013) e estabeleceram o Sumak Kawsay/Buen Vivir e o Suma Qamaña/Vivir Bien como princípios transversais das ações governamentais e do novo projeto de Estado. A concepção de Sumak Kawsay/Buen Vivir está no preâmbulo da constituição do Equador.

Nós, o povo soberano do Equador reconhecendo nossas raízes milenares, forjadas por mulheres e homens de distintos povos, celebrando a natureza, a Pacha Mama, da qual somos parte e que é vital para nossa existência, invocando o nome de Deus e reconhecendo nossas diversas formas de religiosidade e espiritualidade, apelando à sabedoria de todas as culturas que nos enriquecem como sociedade, como herdeiros das lutas sociais de libertação frente a todas as formas de dominação e colonialismo e com um profundo compromisso com o presente e o futuro, decidimos construir uma nova forma de convivência cidadã, em diversidade e harmonia com a natureza para alcançar o Buen Vivir, o Sumak Kawsay; uma sociedade que respeita em todas suas dimensões, a dignidade das pessoas e das coletividades; um país democrático, comprometido com a integração latino-americana sonho de Bolívar e Alfaro - a paz e a solidariedade com todos os povos da terra (EQUADOR, 2008, tradução e grifo nosso).

Institucionalmente o reconhecimento, no âmbito formal, das cosmovisões indígenas, através do Sumak Kawsay/Buen Vivir, poderia significar uma mudança histórica na política do país, assim como, na concepção de desenvolvimento (LE QUANG; VERCOUTÉRE, 2013). O Buen Vivir é a tradução para o espanhol (ou mestiça) da expressão Sumak Kawsay dos povos Kichwas ${ }^{4}$. Conforme as discussões de intelectuais indígenas e não indígenas, o Sumak Kawsay/Buen Vivir representa uma concepção de vida distante dos parâmetros mais caros à modernidade

\footnotetext{
${ }^{2}$ O debate sobre a notoriedade do Buen Vivir é feito por Matthieu Le Quang (2013) e René Ramírez (2012).

${ }^{3} \mathrm{Ambas}$ as constituições foram aprovadas por referendo, a Equatoriana, em setembro de 2008, com 63,93\% dos votos e a Boliviana, em janeiro de 2009 , com $61,43 \%$. O voto é obrigatório em ambos os países. Disponível em http://www.asambleanacional.gov.ec/documentos/Constitucion-2008.pdf. Acesso em 05 ago. 2014.

${ }^{4}$ Existem diferentes formas de escrita para esta palavra, aparecendo como Kichwa, quechua, quéchua e quichua. Neste trabalho adotamos a grafia mais comumente utilizada em textos acadêmicos em espanhol que é Kichwa.
} 
ocidental/capitalista/eurocêntrica e ao crescimento econômico. Este paradigma questiona a relação custo-benefício como axiomática social, o individualismo, a busca pelo lucro, a exploração da "natureza", a relação estratégica entre os seres humanos, a mercantilização total de todas as esferas da vida humana e de outras as formas da vida (ARCINIEGAS; SCHUBERT, 2015; HUANACUNI, 2010).

A compreensão/aceitação da cosmovisão subjacente ao Sumak Kawsay/Buen Vivir poderia representar a possibilidade de construir uma outra sociedade, fundada em valores respeitosos com a "natureza" e com a vida em toda variedade de manifestações. E, desta forma, enfrentar a crise planetária, econômica, ética e política, constituindo-se como um paradigma contra-hegemônico ao modelo que fundamenta o projeto civilizacional da modernidade eurocêntrica, colonialista e capitalista (DUQUE, 2019; DUSSEL, 2016; LANDER, 2016; QUIJANO, 2010; QUINTERO, 2015).

A Constituição do Equador de 2008 é a primeira no mundo a reconhecer os direitos da "natureza", que passa a ser a Mãe Terra (Pachamama), um organismo vivo e, portanto, merecedor da proteção constitucional. No capítulo sétimo constam os "Direitos da Natureza", que em seu artigo 71, dispõe: "a natureza ou Pacha Mama, onde se reproduz e se realiza a vida, tem direito a que se respeite integralmente a sua existência e a manutenção e regeneração de seus ciclos vitais, estrutura, funções e processos evolutivos". E no artigo 74: "[...] o Estado incentivará as pessoas naturais e jurídicas e os entes coletivos, para que protejam a natureza e promovam o respeito a todos os elementos que formam um ecossistema ${ }^{5 "}$.

No entanto, mesmo depois da aprovação da Constituição de Montecristi ${ }^{6}$ em 2008, vêm sendo implementadas políticas de cunho desenvolvimentista e, sobretudo, práticas extrativistas. Ao mesmo tempo, difunde-se um discurso em defesa dos direitos dos povos indígenas, baseado no reconhecimento do Sumak Kawsay/Buen Vivir, como objetivo social a ser cumprido desde as políticas públicas do Estado (ARCINIEGAS; SCHUBERT, 2015).

Esta situação levou o movimento indígena e ecologista a tecer duras críticas ao Estado equatoriano, acusando-o de manter estruturas desenvolvimentistas nas relações econômicas e sociais (ARCINIEGAS; SCHUBERT, 2015). Principalmente quando se considera que a Constituição estabelece que a finalidade do desenvolvimento seja o Sumak Kawsay/Buen Vivir, "o que implica uma ruptura conceitual com a interpretação do desenvolvimento das últimas seis décadas" (ESCOBAR, 2005, p.72) ou, como observa Acosta (2009, p.6), o Buen Vivir "representa uma oportunidade de construir coletivamente um novo regime de desenvolvimento".

EQUADOR. Constitución de la República del Ecuador. 2008. Disponível em: https://www.oas.org/juridico/pdfs/mesicic4_ecu_const.pdf. Acesso em: 5 out. 2018.

6 “Montecristi é o nome de um município do Equàdor, localizado na província de Manabí, no litoral noroeste do país. Foi escolhido como sede da Assembleia Constituinte que entre 30 de novembro de 2007 e 25 de outubro de 2008, debateu, escreveu e aprovou a atual Constituição da República do Equador, reconhecendo em seu primeiro capítulo, o caráter 'intercultural' e 'plurinacional' do país" (ACOSTA, 2016a, p.19). 
Desta forma, para além da complexa trama que envolve a disputa sobre as interpretações acerca do Sumak Kawsay/Buen Vivir, temos então uma questão central: como chegar ao denominado "desenvolvimento para o Sumak Kawsay/Buen Vivir"? Esta incoerência se expressa quando o Estado opera de forma contrária ao que está previsto na Constituição, sobretudo, no que tange à proteção da "natureza" e dos povos ancestrais, adotando práticas extrativistas em áreas protegidas.

A Iniciativa Yasuni-ITT cuja proposta era manter inexplorados os campos de petróleo no Parque Nacional de Yasuní (PNY), tinha absoluta consonância com a proposta da Constituição Equatoriana que preconiza o Sumak Kawsay/Buen Vivir, um desenvolvimento respeitoso com a Mãe Terra, considerando seus ciclos de reprodução e a proteção dos ecossistemas. A inovadora proposta do Equador chamou a atenção mundial ao pretender reverter a extração e produção de matérias-primas, ou seja, de bens primários que sustentam uma economia extrativista. Esta modalidade de acumulação, que começou a ser estruturada há quinhentos anos, com a "conquista" e a colonização da América, da África e da Ásia, fez com que os países colonizados exportassem a "natureza" (ACOSTA, 2016b).

O presidente do Equador apresentou na Assembleia Geral da Organização das Nações Unidas (ONU), em 2007, um projeto ambiental denominado "Iniciativa Yasuni-Ishpingo-Tambococha-Tiputini (YasuniITT)". Através do qual, o governo assumia a responsabilidade de não explorar as reservas de petróleo correspondentes aos campos ITT no Parque Nacional de Yasuni (PNY), na Amazônia equatoriana, indefinidamente.

Desta forma, deixaria debaixo da terra, aproximadamente 856 milhões de barris de petróleo (20\% das reservas comprovadas de petróleo do país) evitando, com isso, a emissão de 410 milhões de toneladas de dióxido de carbono $\left(\mathrm{CO}_{2}\right)$, garantindo, assim, a conservação da biodiversidade e o respeito aos povos indígenas isolados (não contatados) e contatados do território localizado no PNY.

O projeto previa que, por não explorar o petróleo destes campos, - país receberia da comunidade internacional uma compensação financeira no valor de $50 \%$ estimado destas reservas petrolíferas. Caso a proposta se concretizasse, o país obteria, portanto, o montante correspondente a US\$ 350 milhões anuais.

Ao manter inexploradas as reservas do Yasuní-ITT, o Equador esperava, como contrapartida, uma contribuição financeira da comunidade internacional, que deveria assumir sua responsabilidade compartilhada e diferenciada em função dos muitos níveis de destruição ambiental provocada pelas diversas sociedades no planeta - particularmente, pelas mais ricas. A proposta não pretendia simplesmente uma compensação

\footnotetext{
${ }^{7}$ A palavra conquista aparece entre aspas para marcarmos nossa posição crítica relativamente aos processos que se deram nestes territórios desde então.
} 
financeira para seguir forçando o desenvolvimentismo, como entendeu o governo equatoriano, mas se inseria na construção do Bem Viver, que não é uma simples proposta de desenvolvimento alternativo, mas, como já vimos, uma alternativa ao desenvolvimento (ACOSTA, 2016a, p.219, grifo nosso).

A proposta da Iniciativa Yasuní-ITT se alicerçava em quatro importantes pilares: a) a proteção do território e, com isso, da vida dos povos indígenas que vivem isolados; b) a conservação da biodiversidade existente (inigualável em todo planeta, a maior já registrada pelos cientistas até o momento (ACOSTA, 2016a); c) o cuidado com o clima global através da manutenção de petróleo no subsolo, evitando, assim, a emissão de 410 milhões de toneladas de $\mathrm{CO}_{2}$; d) "dar o primeiro passo rumo a uma economia pós-petrolífera, 0 que teria um efeito demonstração em outras latitudes" (ACOSTA, 2016a, p. 218). E como quinto pilar:

\begin{abstract}
assumir a possibilidade de encontrar, coletivamente, respostas concretas aos graves problemas mundiais derivados das mudanças climáticas, provocadas pelo próprio ser humano e exacerbadas especialmente nesta última fase de expansão global do capital (ACOSTA, 2016a, p.218-219).
\end{abstract}

A proposta, paulatinamente, foi ganhando adesões dentro e fora do Equador, o ex-presidente da Assembleia da Organização das Nações Unidas (ONU), argumentou: "a Iniciativa Yasuní-ITT é a proposta mais concreta que se apresentou na história da humanidade para lutar contra a mudança climática e o aquecimento global; significa passar da retórica aos fatos concretos" ${ }^{8}$. David Batker, fundador de ONG Earth Economics, com sede em Tacoma (Estados Unidos), declarou que a Iniciativa YasuniITT representava a liderança mundial na luta contra o aquecimento global.

O projeto ambiental angariou simpatias - além de ser inovador no Equador - possui uma transcendência simbólica "ao representar uma alternativa entre o modelo atual de desenvolvimento, baseado na extração não sustentável de "recursos naturais" e um modelo futuro voltado ao respeito da natureza, à diversidade cultural e à satisfação das necessidades humanas" (LARREA, 2007, p. 28, tradução nossa). Estava previsto que os recursos advindos da Iniciativa constituiriam um fundo administrado pelo Programa das Nações Unidas para o Desenvolvimento (PNUD) e seriam investidos para desenvolver energias renováveis (hidráulica, geotérmica, eólica e solar).

A Iniciativa Yasuni-ITT evitaria a extração e o consumo de milhões de toneladas de $\mathrm{CO}_{2}$. Além disso, pode-se mencionar os benefícios

\footnotetext{
8 Discurso Yasuni-ITT ante la ONU, Nova Iorque, set. 2011. Disponível em: http://www.presidencia.gob.ec/wp-content/uploads/downloads/2014/01/2011-09-23-Discurso-Yasuni-Itten-la-Onu-New-York.pdf. Acesso em: 06 jul. 2016. (ANEXO II)
} 
associados ao desmatamento evitado, à reflorestação, uma maior eficiência energética e o desenvolvimento de energias renováveis. Assim, as emissões que seriam evitadas somariam entorno de 800 milhões de toneladas de $\mathrm{CO}_{2}$ nos próximos 30 anos. Através da Iniciativa Yasuní-ITT poder-se-ia evitar a emissão de milhões de toneladas de $\mathrm{CO} 2$ na atmosfera, representando uma contribuição do Equador na luta contra o aquecimento global (LE QUANG; VERCOUTERE, 2013).

A proposta não compreendia tão somente uma compensação econômica (ACOSTA, 2016a), muito embora não se possa desconsiderar esta dimensão. Ali encerravam-se outros sentidos epistemológicos e simbólicos, visando representar a aposta em uma alternativa ao desenvolvimento (o qual ainda é percebido, quase que exclusivamente, como crescimento econômico e progresso linear) e não de desenvolvimento.

Esta ambiciosa proposta relaciona-se de forma direta com o Sumak Kawsay/Buen Vivir estabelecido na Constituição Equatoriana de 2008, sobretudo, no que tange à proteção aos direitos da "natureza". A Pachamama (Mãe Terra) é o espaço em que se reproduz e se realiza a vida, sendo necessário, portanto, superar a visão utilitarista, segundo a qual a natureza é percebida como um recurso mercantilizável a ser explorado.

O abandono da Iniciativa Yasuní-ITT e, consequentemente, a liberação de exploração de petróleo nestes campos é emblemático, por vários motivos, principalmente pela aposta na possibilidade de outro modelo de desenvolvimento que representou. $O$ anúncio da exploração de petróleo nos campos de ITT por parte do governo gerou muitas manifestações de movimentos indígenas e ecologistas.

A exploração de petróleo no campo foi aprovada pelo Congresso Equatoriano no ano de 2014. O presidente anunciou que no dia 07/09/2016 dar-se-ia, oficialmente, o início da exploração de petróleo no campo Tiputini $^{9}$, em parte localizado na área de influência da Reserva Étnica Waorani (REW), dentro do Parque Nacional Yasuní (PNY) na Amazônia Equatoriana.

Os poços onde a exploração já ocorre estão fora da reserva do Parque Nacional Yasuni (PNY), grupos de ambientalistas e indígenas demonstraram preocupação com a proximidade da área. O campo de Tambococha, de onde será extraído petróleo a partir do ano 2017, fica no limite de Yasuni, e a maior parte do campo ITT está localizada dentro da reserva.

No mapa da figura 1, pode-se analisar com maior precisão os blocos petroleiros. Observando atentamente o bloco 43, o qual abarca os campos de ITT, percebemos que este atinge muitas comunidades indígenas.

\footnotetext{
${ }^{9}$ O início da extração no campo de Tiputini fez com que o Equador batesse o seu recorde de produção diária de petróleo. Nesse campo, são extraídos atualmente 23 mil barris diários. Os três campos Ishpingo, Tambococha e Tiputini — têm reservas de 1,6 bilhões de barris, o que significa $\mathbf{2 0 \%}$ do total das reservas de petróleo do país.
} 
Figura 1: Mapa com os blocos petroleiros dentro Parque Nacional Yasuni e as comunidades indígenas

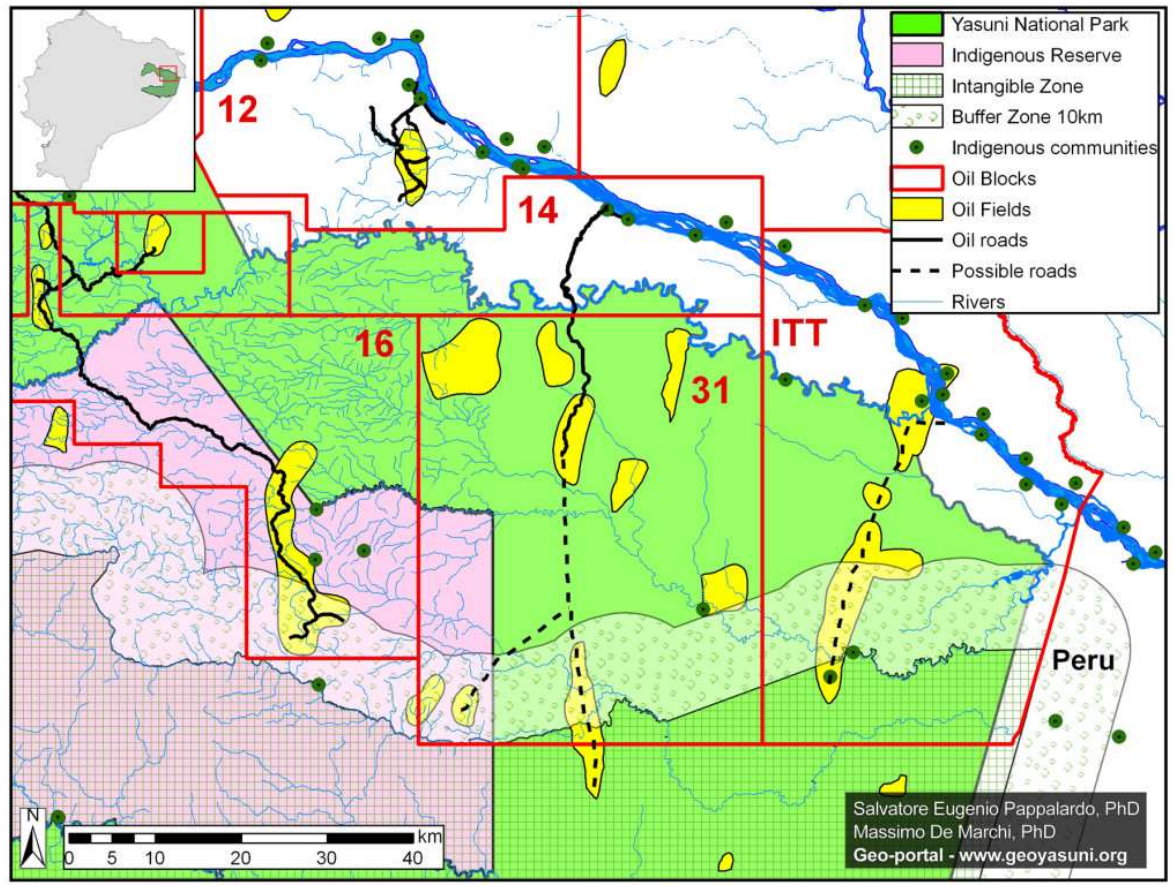

Fonte: PAPPALARDO; DE MARCHI; FERRARESE, 2013.

Os campos de ITT estão na zona conformada pelo bloco 43. A exploração neste bloco atinge toda Zona de Amortecimento e parte da Zona Intangível dos povos Tagaeri Taromenane (ZITT): "uma parte do bloco ITT pertence a ZITT e a exploração do petróleo desta zona agravaria as múltiplas agressões das quais são vítimas os povos destes territórios. Constituiria, além disso, uma infração aos direitos internacionais destas populações" (LE QUANG, 2013, p.26, tradução nossa).

Neste sentido, é ilustrativa a entrevista do ex-ministro de Minas e Energia, o qual foi responsável pela proposição da Iniciativa Yasuni-ITT junto ao governo de Rafael Correa.

Para justificar a necessidade da Iniciativa Yasuni e a não exploração dos campos ITT apresentamos razões éticas indiscutíveis. Nesta área vivem povos indígenas não contatados, povos em isolamento voluntário: os Tagaeri, os Taromenane e os Oñamenane (parte da nacionalidade Waorani). Portanto, temos uma responsabilidade enorme. A atividade petroleira da companhia ChevronTexaco, entre os anos sessenta e noventa do século $X X$, provocou a desaparição de povos inteiros, os Tetetes, os Sansahauris. As vozes, os risos, os comentários, as brincadeiras, os cantos, as invocações destes povos nunca mais voltaremos a ouvir; desapareceram todos. Foi um choque com a "cultura ocidental e cristã" que exterminou estes povos. E para completar a tragédia, de forma muito irônica, os nomes destes povos desaparecidos servem para denominar os campos 
petroleiros no norte da Amazônia Equatoriana, em que antes viviam estes povos. E mais sobre a Texaco recai também todos os danos econômicos, sociais e culturais causados aos indígenas Siona, Secoya, Cofán, Kichwa e Waorani. No âmbito psicossocial as denúncias são múltiplas: violência sexual por parte dos operadores da companhia contra as mulheres adultas e adolescentes mestiças e indígenas, abortos, discriminação e racismo, deslocamentos forçados, nocivo impacto cultural e ruptura da coesão social (informação verbal) ${ }^{10}$.

A Zona Intangível dos povos Tagaeri Taromenane (ZITT) dentro do Parque Nacional Yasuní (PNY) foi estabelecida a partir do decreto presidencial ( $n^{\circ}$ 552) de 1999, no marco das medidas cautelares expedidas pela Comissão Interamericana de Direitos Humanos (CIDH). O decreto prevê que nestas zonas é vedada, indefinidamente, a atividade extrativista, incluindo a atividade petroleira, com o objetivo de garantir a vida e a existência dos povos indígenas isolados (não contatados). As zonas intangíveis são "espaços protegidos de grande importância cultural e biológica, nos quais não se pode realizar nenhum tipo de atividade extrativa devido ao alto valor que têm para a Amazônia, para o Equador, para o mundo e para as gerações atuais e futuras" (EQUADOR, 1999).

A ZITT abarca aproximadamente 700 mil hectares da zona sul do Parque, equivalente ao núcleo do PNY e parte do território dos Tagaeri Taromenane; dois grupos indígenas pertencentes à etnia Waorani que vivem na Amazônia Equatoriana, entre os rios Yasuní e Curaray, compartilhando o território com outros grupos Waorani.

\section{A pesquisa de campo}

Em termos territoriais a pesquisa com as comunidades indígenas ocorreu através de nossa instância na Fundação Alejandro Labaka na cidade de Puerto Francisco de Orellana (conhecida como Coca), na Região Amazônica Equatoriana (RAE), no ano de 2017. No tempo que estivemos na referida fundação convivemos diretamente com grupos indígenas das etnias Kichwas e Waoranis. Nossa permanência na RAE nos permitiu um contato intenso com estes grupos. Enquanto se desenrolava o café da manhã ou almoço, aproveitávamos para conversar, conhecer a cultura de cada grupo, seus senti-pensares. Nosso principal foco de interesse era compreender como percebiam a proposta da Iniciativa Yasuni-ITT e a exploração de petróleo em seus territórios. Por isso, neste tempo-espaço foi possível uma convivência comunitária e, partindo de uma lógica decolonial, não diríamos que os entrevistamos.

Minhas inquietações sobre a metodologia de pesquisa se agravaram neste espaço-tempo; senti fortemente os limites da forma de

\footnotetext{
${ }^{10}$ Entrevista concedida por A. A Entrevista VII [Set. 2017]. Entrevistador: autora. Quito, 2017. 1 arquivo .mp3 (120 min.). A. A. Economista, ex-ministro de Minas e Energia do governo Rafael Correa, responsável pela Iniciativa Yasuni-ITT. Tradução da autora.
} 
fazer pesquisa eurocêntrica. O campo me propiciou refletir sobre meu lugar como pesquisadora. A convivência com os grupos indígenas permitiu compreender que "estas propostas investigativas são insuficientes e não garantem o desenvolvimento de um verdadeiro processo decolonizante, já que através delas não é possível conhecer as características de sujeitos ou de processos somente através de um breve encontro com eles" (ORTIZ; ARIAS; PEDROZO, 2018b, p. 176, tradução nossa).

Não dispunha de um referencial teórico que me amparasse na realização de uma pesquisa que pudesse ser denominada decolonial. Todavia, mergulhei numa crise com muitos atravessamentos até chegar no território amazônico e conviver com estas populações. A academia ainda é muito eurocentrada, então assumo, em parte, a responsabilidade, pelos vazios formativos na perspectiva decolonizante. Castro-Gomez (2007 apud ORTIZ; ARIAS; 2019, p.91) afirma "que o diálogo de saberes só é possível através da decolonização do conhecimento e das instituições produtoras e administradoras do conhecimento".

A investigação foi assumida no território Abya Yala como um processo desumanizante, um conjunto de ações "colonizantes" que causaram dor e sofrimento. O imperialismo, o capitalismo e o colonialismo constituem a tríade que configura a investigação como mecanismo de domínio, regulação e controle mediante a criação de noções autoritárias que se transformam em argumentos para manipular e obrigar, como são os conceitos de objetividade, verdade e realidade externa. Alguns acadêmicos e intelectuais do ocidente, personalidades eurocentradas, assim como as instituições patrocinadas pelo Estado, regulam, controlam e colonizam mediante o estabelecimento de regras formais e normas universais para gestar a ciência e a academia, mediante paradigmas científicos impostos e através de metodologias rígidas e dogmáticas, cujo resultado é a colonialidade científica (ORTIZ, ARIAS, PEDROZO, 2018b, p.174).

Neste sentido, devemos estar atentos aos processos de colonialidade científica, buscando questionar as práticas de investigação que reproduzem mecanismos de domínio, regulação, invizibilização e controle.

No início da permanência junto aos povos indígenas, eu tinha um roteiro de entrevista semiestruturado. Existia uma angústia em realizar as entrevistas. Todavia, com o passar dos dias, fui percebendo que o mais importante para aprender era observar, conviver e, claro, escutá-los. Ainda não tinha um referencial teórico para isso, mas intuitivamente me incomodava o fato de adotar uma perspectiva teórica decolonial e sentir que de alguma forma colonizava os sujeitos com quem estava convivendo. Muitas inquietações sobrevoavam a minha mente: será possível conhecer, ao menos em parte, suas cosmovisões sem conviver, 
sem mergulhar nestas racionalidades profundas encarnadas e resignificadas em cada ato? A permanência no campo estilhaçou de forma brutal minha compreensão sobre o ato de pesquisar. Então, me perguntei: como adentrar em universos simbólicos tão distintos? Como romper com a lógica sujeito-objeto na pesquisa? Neste sentido, entre tantas questões/percepções que atravessaram meu horizonte de sentir/imaginar, destaco o seguinte questionamento: como superar a forma ocidentalizada de fazer ciência? Como estabelecer uma relação sujeito-sujeito na pesquisa?

Me parece urgente "configurar novas formas de fazer ciência antropossocial, reinventar a investigação social e humana, propor novas práticas investigativas que não colonizem o investigado e que não convertam o investigador em um colonizador" (ORTIZ; ARIAS; PEDROZO, 2018 b, p.175, tradução nossa). As interrogações suscitadas pelo campo foram e são válidas, na medida em que permitem seguir questionando as formas de fazer pesquisa da ciência ocidental. Uma das saídas encontradas, ainda em campo, foi a decisão de abandonar o roteiro de entrevista e conviver, estar junto, auxiliar no trabalho, conversar, estar com todos os sentidos disponíveis e abertos para o "Outro". Não foi um exercício fácil, sendo intensificado pelo fato de eu não falar Kichwa ou Waorani. Então, nosso encontro se produzia numa travessia de idiomas. Era um desafio porque o espanhol não é nem para mim, nem para eles, a língua materna.

Autores como Ortiz (2017a, 2017b, 2017c), Ortiz e Arias (2019), e Ortiz, Arias e Pedrozo (2018a, 2018 b) contribuem com importantes ideias sobre as bases e traços característicos do que denominam um "fazer decolonial". Em suas reflexões e análises questionam por quê e para quê uma metodologia outra, bem como a urgente necessidade de caminhar rumo a um processo decolonizante. Os autores compreendem o fazer decolonial como um processo decolonizante, desenvolvido através de ações como: o observar comunitário, o conversar alternativo e o reflexionar configurativo. Segundo Ortiz e Arias (2019, p. 92, tradução nossa) "emerge assim o fazer decolonial não como uma nova metodologia, mas como uma opção, como uma forma outra de conhecer, pensar, ser, fazer e viver".

Certamente, temos um longo caminho rumo a uma metodologia de pesquisa decolonial. Existem muitas questões a serem visibilizadas, situações que precisam ser ditas pelos seus nomes, afinal, são processos históricos de negação e encobrimento. Decolonizar a metodologia de pesquisa pressupõe não somente deselitizar e desmistificar a investigação e a produção científica e intelectual, mas reconhecer que a academia se constitui historicamente como um lócus privilegiado, que possui um ethos cuja prática radica em regurgitar aquilo que lhe é estranho e que as tentativas de crítica são ainda muito tímidas. Um primeiro passo seria assumir que existe uma academia colonial/neocolonial/capitalista/eurocêntrica e compreender o que implica a produção de conhecimento desde esta perspectiva. Ficam 
alguns pontos para sentipensar ${ }^{11}$ : como produzir processos de ruptura? como gerar brechas? como visibilizar outros saberes e práticas na academia ocidental? Ou, de outra forma, como decolonizar a ciência e a produção de conhecimento? Estes questionamentos podem também ser entendidos como resultado do campo.

Levando em conta estas reflexões e questionamentos, a seguir dispomos um quadro com informações gerais sobre os sujeitos da pesquisa. Nele expomos o número da entrevista, tal qual observada nas notas de rodapé quando citamos estes sujeitos, o vínculo principal do entrevistado, o grupo social de qual faz parte e localidade de pertencimento/convivência.

Quadro 1: Informações gerais sobre os sujeitos da pesquisa

\begin{tabular}{|c|c|c|c|}
\hline $\begin{array}{l}\text { Entre- } \\
\text { vista }\end{array}$ & Vínculo & Grupo Social & Localidade \\
\hline I & Geógrafo & $\begin{array}{l}\text { Yasunidos, coletivo de geógrafos } \\
\text { críticos e ONG Acción Ecológica }\end{array}$ & Quito, Equador \\
\hline II & $\mathrm{Dr}^{\mathrm{a}}$ em Antropóloga & Professora da FLACSO & Quito/ Equador \\
\hline III & Sociólogo & Fundação Alejandro Labaka & Coca/ Equador \\
\hline IV & $\begin{array}{l}\text { Liderança indígena } \\
\text { Kichwa }\end{array}$ & $\begin{array}{l}\text { Confederação das Nacionalidades } \\
\text { Indígenas do Equador (CONAIE) }\end{array}$ & Quito/ Equador \\
\hline V & $\begin{array}{l}\text { Indígena Shuar, } \\
\text { Assessor de projetos }\end{array}$ & Fundación Alejandro Labaka & Coca/ Equador \\
\hline VI & Indígena Waorani & Associación OME Yasuni & Coca/ Equador \\
\hline VII & Economista & $\begin{array}{l}\text { Ex-Ministro de energia no governo de } \\
\text { Rafael Correa } \\
\text { Pesquisador do Sumak Kawsay. } \\
\text { Responsável pela Iniciativa Yasuni-ITT. }\end{array}$ & Quito/ Equador \\
\hline VIII & Indígena Waorani ${ }^{12}$ & & $\begin{array}{l}\text { Bloco } 43- \\
\text { Amazônia/ } \\
\text { Equador }\end{array}$ \\
\hline IX & Indígena Shuar $^{10}$ & & Coca/ Equador \\
\hline$X$ & $\begin{array}{l}\text { Indígena Kichwa } \\
\text { amazônico }\end{array}$ & $\begin{array}{l}\text { Guia turístico } \\
\text { Integrante da organização Amauta } \\
\text { Ecotur }\end{array}$ & $\begin{array}{l}\text { Pastaza/ } \\
\text { RAE/Equador }\end{array}$ \\
\hline XI & $\begin{array}{l}\text { Investigador, } \\
\text { advogado, gestor } \\
\text { ambiental, especialista } \\
\text { em filosofias andinas }\end{array}$ & $\begin{array}{l}\text { Pesquisador e autor de vários livros } \\
\text { sobre o Sumak Kawsay }\end{array}$ & Equador/Bolívia \\
\hline XII & $\begin{array}{l}\text { Técnico da } \\
\text { Nacionalidades } \\
\text { Waoranis do Equador } \\
\text { (NAWE) }\end{array}$ & $\begin{array}{l}\text { Nacionalidades Waoranis do Equador } \\
\text { (NAWE) }\end{array}$ & RAE/Equador \\
\hline
\end{tabular}

Fonte: Elaboração própria.

\footnotetext{
${ }^{11}$ Com a expressão "sentipensar", o autor De la Torre (2018) apresenta o processo mediante o qual se configuram pensamento e sentimento, duas formas de interpretar a realidade, mediante a reflexão e a emoção até que se convertam em um mesmo ato de conhecimento e ação.

${ }^{12}$ Aparecem alguns atores indígenas sem identificação de grupo social. Isso porque estes entrevistados não faziam parte de nenhuma organização e entrevistá-los foi uma escolha da autora para não ouvir somente os indígenas que tem vinculação com os movimentos.
} 


\section{A iniciativa Yasuni-Itt e a exploração de petróleo nos territórios desde a perspectiva dos povos indígenas}

O território como algo a ser explorado ou, em última instância, como um "recurso natural", traz em si certa racionalidade instrumental e uma carga simbólica de colonialidade do poder. Para os indígenas Waoranis com quem convivi, o território tem outros significados. Uma das lideranças dos povos Waoranis que vive no PNY nos comentava como estes povos percebem o território:

Sou da comunidade de Bameno, pertenço a associação Ome Yasuní. Vivo na Zona Intangível Yasuní. A selva é território ancestral para os povos Waoranis, das famílias em isolamento. A selva é para nós a casa onde vivemos, também vivem as famílias Taromenani e Tagaeri e somos todos família Waoranis. Vivemos na mesma selva, falamos o mesmo idioma, a mesma vida e cultura. Como nós dizemos, quando chega a civilização do branco, quando a empresa Texaco chegou a este país, chegou na Amazônia Equatoriana, nós sofremos muito, nós perdemos nossos territórios. Agora as petroleiras querem chegar em todos os lados do território, vão destruir tudo e onde vamos viver? Sem território não vivemos. Onde vão viver nossos filhos, as futuras gerações? Por isso pedimos algo que possa ficar para nossos filhos e nossa família Waorani. Queremos viver em nossa selva sem a exploração de petróleo (informação verbal) ${ }^{13}$.

O que significa território para os indígenas amazônicos equatorianos da etnia Waorani? Vejamos, eles aludem "nossa selva", "nossa casa", "nossa família". É necessário atentar para o fato que a expressão "nossa selva" não remete a uma racionalidade instrumental de "propriedade da terra" como seria, por exemplo, ser dono de uma vasta extensão de terra, mas tem uma relação com o vivido. O excerto abaixo é ilustrativo de como este ator percebe a relação que a sociedade ocidental estabelece com a terra.

Sabemos que o homem branco não compreende nossos costumes. Para ele uma porção de terra tem o mesmo valor que outra coisa qualquer, pois um forasteiro chega de noite e extrai da terra aquilo que necessita e vai embora. A terra não é sua mãe, mas é sua inimiga e quando já a conquistou segue seu caminho (informação verbal $)^{14}$.

\footnotetext{
${ }^{13}$ Entrevista concedida por P.B. Entrevista VI. [Out. 2017]. Entrevistador: autora. Coca, 2017. 1 arquivo.mp3 (90 min.). P.B. Liderança Waorani, é representante da Associação OME Yasuní, vive na comunidade de Bameno em Pastaza, Região Amazônica Equatoriana (RAE). Tradução da autora.

${ }^{14}$ Entrevista concedida por P.B. Entrevista VI. [Out. 2017]. Entrevistador: autora. Coca, 2017. 1 arquivo.mp3 (90 min.). P.B. Liderança Waorani, é representante da Associação OME Yasuní, vive na comunidade de Bameno em Pastaza, Região Amazônica Equatoriana (RAE). Tradução da autora.
} 
O território para os povos indígenas tem um aspecto relacional importante porque é onde viveram e estão enterrados seus antepassados. Desta forma, as diversas dinâmicas que implicam o viver se dão no território; tem-se uma inversão: não é o território que pertence aos povos indígenas, como seria numa perspectiva de propriedade dentro de uma lógica ocidental, mas eles é que pertencem ao território. Como eles dizem: eu sou desta terra, eu sou deste lugar, eu sou daqui.

Além da perspectiva diferenciada sobre o território, há também outra compreensão do tempo, pois o tempo não é linear, com etapas sucessivas, mas é cíclico. Por isso, os ancestrais, os avôs, os espíritos (os apus), estão coexistindo neste tempo-espaço, estão presentes "falando" com os humanos e não humanos. Do que pude perceber através da vivência em campo, o território não remete a um lugar específico, mas a uma trama complexa de relações de reciprocidade e cuidado. Desta forma, não há como compreender o sentido de território para os povos indígenas Waoranis sem antes entender estas relacionalidades profundas, encarnadas nestas vivências/sentires.

Estas relacionalidades são laços familiares e de parentesco com outros humanos, mas são também a relação com todos os outros seres vivos e não vivos que conformam esta teia de relações. A ideia de que os rios, as montanhas, as árvores são irmãos contém em si uma relação profunda não só de inseparabilidade do homem e da natureza, mas uma relação de complementariedade e de reciprocidade. Do que pude observar em campo, a relação com o território é de cuidado e espiritualidade e é mediada por questões sagradas.

Temos então elementos do Sumak Kawsay através deste componente de espiritualidade, uma visão segundo a qual não existem partes, não existe a separação, tão cara à episteme moderna, homemnatureza ou sociedade-natureza ou, ainda, cultura-natureza. A ideia subjacente é que somos todos um, estamos todos conectados. Desta forma, os rios, as árvores e as plantas não são exteriores a nós, humanos, mas são nossos irmãos. Por isso, a terra é a Mãe Terra, a Pachamama, a quem devemos reverenciar e da qual somos parte. O território é algo sagrado. Este caráter espiritual dificilmente pode ser entendido pelos preceitos forjados pela racionalidade instrumental capitalista/moderna/eurocêntrica ${ }^{15}$.

No caso da região amazônica, historicamente estas populações habitavam estes territórios sem realizar a exploração "intensiva" do que denominamos "recursos naturais" pela racionalidade instrumental capitalista. Neste sentido, é pertinente retomar parte da fala do entrevistado que discute o Sumak Kawsay como uma tradição e filosofia andina:

\footnotetext{
${ }^{15}$ Neste sentido, a importância de decolonizar nosso imaginário, porque nossa formação educativa e cultural em todos os âmbitos é ocidentalocêntrica. Assim, nossa educação nos inculca valores e quais são os valores que aprendemos: a competição, o egoísmo, o consumismo, o sucesso é ter mais que o outro. Precisamos nos desprender deste imaginário.
} 
Isto representa o equilíbrio. Quando o movimento indígena aborda a questão da relação harmoniosa com a "natureza", eles referem que estão tratando de recompor o equilíbrio, ou seja, buscar não explorar mais que a Pachamama possa suportar. Viver em harmonia não representa algo como o "paraíso" terrestre, mas remete a uma ideia de equilíbrio, respeito, solidariedade, complementariedade e reciprocidade" (informação verbal) ${ }^{16}$.

Neste excerto temos um elemento importante que merece destaque porque justamente uma das críticas que recai sobre a concepção de Sumak Kawsay é sobre a relação harmoniosa com a natureza. Existe, neste ponto, certo reducionismo na compreensão do que significa uma relação harmoniosa, a qual nos parece muito bem explicada na ideia de recompor o equilíbrio, de não consumir mais que os ecossistemas possam suportar.

A visão instrumental e utilitária da natureza e, mais do que isso, a exploração intensiva e as práticas depredadoras próprias de um capitalismo nascente se fizeram presentes nos territórios do que hoje conforma a América Latina e Caribe desde seus inícios. Neste sentido, a chegada de Cristóvão Colombo ao continente americano em 1492 constituiu o anúncio de uma longa cadeia de saqueio e extração dos recursos naturais de nossa região, a qual continuou de forma ininterrupta durante mais de cinco séculos (LO BRUTTO; VAZQUEZ SALAZAR, 2015, p. 56, tradução nossa).

O território amazônico equatoriano viveu várias etapas de exploração - de pele, de borracha, de madeira e, mais recentemente, de petróleo - e esteve à mercê das empresas exploradoras e das missões religiosas. Esta região assumiu uma importância econômica estratégica devido às descobertas das reservas de petróleo e ao preço dos commodities no mercado internacional nos últimos anos. A entrevista da liderança indígena Waorani é representativa de como eles percebem o papel do Estado em seus territórios. Há uma referência explícita à intervenção governamental na delimitação das áreas:

Antes todo território (da Amazônia) era nosso. Depois no ano de 1988 o governo declarou o Parque Nacional Yasuni e em 1999 criaram a Zona Intangível Tagaeri Taromenane (ZITT). Agora a gente nem pode mais caçar e levar uma caça para dar de presente para um parente.

\footnotetext{
${ }^{16}$ Entrevista concedida por A.O.F. Entrevista XI [out. 2020]. Entrevistador: autora. Porto Alegre, 2020. 1 arquivo .mp3 (100 min.). A.O.F. Investigador, advogado, gestor ambiental, especialista em paradigmas andinos.. Tradução da autora.
} 
É proibido. O Estado não deixa, eles é que decidem o que podemos fazer no nosso território (informação verbal) ${ }^{17}$

Uma das nacionalidades que habita esta região são os povos Waoranis, considerados de recente contato, porque somente a partir dos anos 1960 que estes povos tiveram um contato mais intensivo com os povos considerados "brancos"18 e "mestiços". É muito interessante o depoimento do sociólogo entrevistado que trabalha na região amazônica:

os povos indígenas amazônicos não eram mais que sombras disformes e fugidias para sociedade equatoriana em geral, mas, com as descobertas das reservas petroleiras, os setores empresarias e alguns setores estatais, passaram a perceber as populações indígenas como um entrave à exploração destes "recursos" (informação verbal) ${ }^{19}$.

Desde o boom petroleiro, nos anos 80 do século $X X$, os indígenas assistiram à ocupação, à exploração e à destruição de seus territórios. Muito embora, a partir de uma perspectiva formal, desde a Constituição de Montecristi de 2008, sejam reconhecidos como sujeitos de direitos e, portanto, merecedores da proteção do Estado.

Como argumenta a liderança indígena em sua entrevista, anteriormente todo território era deles e eles tinham, portanto, a possibilidade de ir e vir livremente para caçar, pescar e coletar. No entanto, como salienta a antropóloga, que possui pesquisas sobre as dinâmicas territoriais na Amazônia: "a instalação dos blocos petroleiros na região amazônica mudou radicalmente o cotidiano e as formas de vida destes povos porque eles foram sendo cada vez mais cercados e ameaçados em seus próprios territórios e houve a desaparição de povos inteiros" (informação verbal) ${ }^{20}$. Existe uma radical mudança nas dinâmicas que se dão nos territórios, devido aos enclaves extrativistas, os quais produzem transformações, muitas vezes irreversíveis para as comunidades.

Nossa luta é para preservar este território, a Iniciativa Yasuni-ITT é apenas um pedacinho deste território. Eu nunca acreditei que o governo não fosse explorar o petróleo destes campos. Creio que a ideia sempre foi

\footnotetext{
17 Entrevista concedida por P.B. Entrevista VI [Out. 2017]. Entrevistador: autora. Coca, 2017. 1 arquivo.mp3 (110 min.). P.B. Liderança Waorani, representante da Associação OME Yasuni, vive na comunidade de Bameno em Pastaza, Região Amazônica Equatoriana (RAE). Tradução da autora.

${ }^{18}$ Mereceria uma discussão os processos de construção social da branquitude e da mestiçagem, todavia, por não ser um dos objetivos deste estudo e exigir um rigoroso aprofundamento teórico, apenas reiteramos que somos críticos a tais processos e que compreendemos a importância desta discussão.

19 Entrevista concedida por D.S. Entrevista III [Out. 2017]. Entrevistador: autora. Quito, 2017. 1 arquivo.mp3 (90 min.). D.S. Sociólogo, coordenador do projeto Povos na Fundação Alejandro Labaka.

${ }^{20}$ Entrevista concedida por L.C Entrevista II [Set. 2017]. Entrevistador: autora. Quito, 2017. 1 arquivo .mp3 (100 min.). L. C. Antropóloga, Professora da FLACSO, pesquisadora das populações amazônicas. Tradução da autora.
} 
explorar, talvez de uma forma menos pior, um pouco menos destrutiva. O bloco 31 já estava sendo explorado, mesmo sem ter a licença legal para isso. Agora vão explorar o petróleo do bloco 43, o bloco de ITT, não sabemos como vamos nos proteger. Com a exploração e a construção das estradas temos medo do que vai restar de nossos territórios e da nossa gente. Por isso temos que lutar, sobretudo, pelos irmãos que vivem em isolamento (informação verbal) ${ }^{21}$.

A Iniciativa Yasuni-ITT, como refere a liderança indígena, representa uma pequena parte do vasto território do Parque Nacional Yasuni (PNY). Ele acredita que a intenção do governo sempre foi explorar, ou seja, nunca houve o real interesse de evitar a exploração de petróleo nos campos de ITT (bloco 43).

Do que pudemos observar em campo, existe negligência por parte do Estado no que tange à proteção dos povos e à conservação dos territórios. De outra parte, existe uma oferta "real" de "bens" e "serviços" por parte das empresas petroleiras. As empresas se utilizam de estratégias de cooptação e divisão das comunidades e das lideranças indígenas. Um dos entrevistados indígenas mencionava preocupação pelo futuro das comunidades, principalmente devido à atuação das empresas que se utilizam da oferta de "presentes" para conseguir o apoio das comunidades. Ele nos contou que:

Eles tratam de tentar comprar os povos. Os grupos petroleiros enviam seus funcionários nas comunidades e oferecem a construção de casas, de escolas, de postos de saúde. Dizem que vão dar televisão, carro e dinheiro. $E$ que vão construir as vias que é para levar o petróleo, mas que os indígenas também se beneficiarão, pois poderão sair de carro das comunidades para a cidade para vender seus produtos. A construção destas vias abre a selva para todo tipo de incursão, exploração. Estes grupos que entram sempre produzem violência. Eles prometem muito para que as pessoas concordem com a exploração na Consulta Livre, Prévia e Informada (CLPI) e depois não dão nada. Eu digo para a comunidade: se eles vêm e exploram, teremos dinheiro para 10 ou 15 anos e depois, não teremos a selva e não teremos nada. Nossos filhos e netos vão viver como? (informação verbal) ${ }^{22}$

\footnotetext{
21 Entrevista concedida por P.B. Entrevista VI [Out. 2017]. Entrevistador: autora. Coca, 2017. 1 arquivo.mp3 (110 min.). P.B. Liderança Waorani, representante da Associação OME Yasuni, vive na comunidade de Bameno em Pastaza, Região Amazônica Equatoriana (RAE). Tradução da autora.

${ }^{22}$ Entrevista concedida por F. C. Entrevista X [Out. 2017]. Entrevistador: autora. PASTAZA, 2017. 1 arquivo .mp3 (60 min.). F.C. Indígena Kichwa amazônico, guia turístico, integrante da organização Amauta Ecotur. Tradução da autora
} 
Além da oferta de "bens" e "serviços", como forma de tentar se aproximar das comunidades e garantir seu apoio para projetos de exploração, as empresas fazem doações de alimentos, roupas, calçados e outros utensílios. Como refere a liderança indígena entrevistada, o consumo de alimentos industrializados altera a dieta dos povos amazônicos e acaba provocando diversas doenças.

As empresas vão nas comunidades e levam sacolas para doar, cheias de pão, refrigerantes, bolachas, todo tipo de doces, pirulitos e balas (principalmente) e iogurtes. 0 consumo deste tipo de alimento provoca a perda de dentes nos adultos e principalmente nas crianças. $O$ consumo de produtos lácteos ocasiona infecções intestinais, porque não somos acostumados a este tipo de dieta. Nossa dieta era principalmente a base de carne de caça, de pesca e de frutas e, mais recentemente, da agricultura. Não utilizamos nem sal e nem açúcar na nossa alimentação. É uma verdadeira desgraça a mudança na alimentação. Estamos muito doentes por causa das mudanças alimentares, principalmente pelo consumo de refrigerante e doces em geral. Eles nos destroem de várias formas, contaminam, trazem a violência e a destruição para comunidade (informação verbal) $)^{23}$.

A questão da mudança na dieta alimentar é um ponto muito importante porque impacta diretamente na saúde das populações indígenas. Assistimos à doação de uma carga de refrigerantes da CocaCola para uma comunidade enquanto estávamos na Amazônia. Isto também representa uma forma de violência e extermínio para estes povos, pois debilita sua saúde, uma vez que não são acostumados ao consumo de açúcar e lácteos, principalmente.

Na ausência da proteção e cumprimento do papel do Estado para com estas populações, existem algumas comunidades que estabelecem relações paternalistas e clientelares com as empresas, aceitando as ofertas de "presentes" das empresas". Tanto assim, que em alguns blocos petroleiros do PNY, os povos indígenas veem como algo "positivo" a exploração, porque acessam algumas benesses (casas, carros, telefones celulares, televisões, quadras de esporte, entre outras coisas) que não teriam se não fosse pelas empresas petroleiras (informação verbal) ${ }^{24}$.

\footnotetext{
${ }^{23}$ Entrevista concedida por F. C. Entrevista X [Out. 2017]. Entrevistador: autora. PASTAZA, 2017. 1 arquivo .mp3 (60 min.). F.C. Indígena Kichwa amazônico, guia turístico, integrante da organização Amauta Ecotur. Tradução da autora.

${ }^{24}$ Entrevista concedida por D. V. Entrevista XII [Out. 2020]. Entrevistador: autora. PASTAZA, 2020. 1 arquivo .mp3 (60 min.). D. V. Técnico da Nacionalidades Waoranis do Equador (NAWE). Tradução da autora
} 
A oferta de "presentes" por parte das empresas resulta atrativa para algumas comunidades, sobretudo, as que estão menos engajadas em movimentos e lutas sociais na defesa dos territórios. A ausência do Estado em cumprir com os direitos básicos e coletivos destas populações tornaas presas fáceis na mão das empresas petroleiras. As empresas prometem suprir as necessidades destas comunidades nas áreas de educação, saúde, lazer, habitação, entre outras. Então, para as comunidades menos acessíveis e mais vulneráveis, e que recebem menos recursos e serviços por parte do governo, tornam-se quase irresistíveis tais ofertas.

E não nos esqueçamos que as populações indígenas estão sob as pressões do paradigma da cultura ocidental que associa felicidade, sucesso e realização aos bens materiais. Então, muitos jovens se identificam e defendem a cultura ancestral e tem uma compreensão muito profunda do que significa a venda dos seus territórios. De outra parte, alguns jovens, sobretudo, os menos engajados nos movimentos indígenas, são mais suscetíveis à sedução das "dádivas" das empresas.

Há também outras estratégias de cooptação e divisão das comunidades e lideranças indígenas pelas empresas petroleiras, situações que impactam diretamente nas relações familiares e de gênero. Embora tenha feito mais entrevistas com homens, as mulheres eram as mais próximas a mim no campo. Quando conheci M.S (mulher indígena da etnia Shuar), conversei várias vezes com ela. Além de me contar sua própria história, um dia ela fez o seguinte relato:

Os funcionários das empresas petroleiras "convidam" os homens para sair, para ir a festas, eles dão bebidas de álcool para os homens. Aí eles se afastam da casa, da família, já querem estar fora de casa, fazendo outras coisas. Eu já ouvi de muitas mulheres, amigas, companheiras indígenas que queriam se matar porque seus maridos saem, mudam os costumes e arrumam outras mulheres da cidade. Daí eles mudam, não querem mais ficar nas comunidades. Antes não era assim, não eram violentos. Às vezes a comunidade se reúne para discutir estes problemas, mas agora bem menos também. Isso está acontecendo em todas comunidades, trazem maus costumes. Existe um aumento da violência contra a mulher indígena e também muito suicídio de mulheres jovens por causa do abandono, da violência e todas outras formas de abuso. E tem ainda os abusos dos funcionários das empresas, principalmente com as mulheres indígenas mais jovens (informação verbal) ${ }^{25 " .}$

Temos neste relato a evidência das várias formas de cooptação das lideranças masculinas e, sobretudo, a questão das transformações das

\footnotetext{
${ }^{25}$ Entrevista concedida por M.S Entrevista IX [Out. 2017]. Entrevistador: autora. Coca, 2017. 1 arquivo .mp3 (60 min.). M. S. Indígena, da etnia Shuar. Tradução da autora.
} 
relações familiares nas comunidades. As mudanças nas relações familiares são, em geral, muito ruins principalmente para as mulheres das comunidades, porque elas veem suas relações familiares diretamente afetadas por estas situações. Existem muitos casos de abandono e violência intrafamiliar contra as mulheres. Fora isso, existe a violência perpetrada por homens externos às comunidades - no caso a violência dos funcionários das empresas para com as mulheres indígenas. No caso da empresa Texaco, estas agressões foram alvo de denúncia em muitas organizações internacionais de direitos humanos. Muito embora, exista um grande número de organizações indígenas, principalmente na defesa dos territórios, que são lideradas por mulheres.

Um ponto que enseja uma análise importante é a Consulta Livre, Prévia e Informada (CLPI) a qual é um direito coletivo, prevista legalmente por diversos organismos internacionais, visando alcançar um "desenvolvimento sustentável"26 dos povos e dos territórios. Segundo López (2016, p. 4, tradução nossa):

Apesar dos importantes avanços no direito que produziu a Constituição de 2008, no Equador se vive um profundo mal-estar devido à distância entre o texto constitucional e a realidade. A CLPI ainda não foi materializada na legislação secundária, nem na institucionalidade estatal, nem no orçamento público e, portanto, não existe na prática. Projetos de exploração mineira, especialmente e várias leis já aprovadas, não levaram em consideração os povos indígenas, suas aspirações e o direito legítimo de construir seu destino.

O artigo 57 da constituição do Equador ${ }^{27}$, na seção 7, garante que os povos indígenas sejam consultados de forma livre, prévia e informada (CLPI) dentro de um período de tempo razoável, sobre planos e programas que visam à prospecção, produção e comercialização de recursos não renováveis, localizados nas suas terras e que possam ter um impacto ambiental ou cultural sobre eles. No entanto, esses direitos foram violados em muitas situações, como no caso do bloco 22 no PNY em que os indígenas Waoranis não foram devidamente consultados, antes do anúncio das novas concessões a empresas petroleiras.

Os enclaves extrativistas causam a contaminação, destruição nos territórios e a expulsão e extermínio dos povos indígenas, conforme nos adverte o entrevistado integrante da ONG Acción Ecológica: "a contaminação das águas causa sérios danos, os elementos presentes nestas águas são cancerígenos, o que resta para as populações após

\footnotetext{
${ }^{26}$ Em vários documentos consta a expressão desenvolvimento sustentável. Todavia, reiteramos nossa crítica a estas novas roupagens que distintas organizações buscaram dar ao desenvolvimento, no intento de humanizá-lo (RADOMSKY, 2011).

${ }^{27}$ Além disto, existem outros dois acordos internacionais do qual o Equador é signatário, que garantem o direito à consulta das populações indígenas: a Convenção 169 da Organização Internacional do Trabalho (OIT), ratificada pela nação em 1998 e a Declaração das Nações Unidas sobre os Direitos dos Povos Indígenas, adotado em 2007.
} 
Espaço Ameríndio

longos períodos de exploração petroleira é degradação e morte" (informação verbal) ${ }^{28}$.

Podemos considerar que a Amazônia se constitui como a periferia dentro da periferia. As faces da violência, da exploração são múltiplas e diversas: destruição do território, todas formas de violência contra os povos e a contaminação do território e as doenças (informação verbal) ${ }^{29}$.

A contaminação da água, do solo e do ar causada pela exploração de petróleo, em muitos casos está muito próxima das casas dos indígenas deste território, o que impacta diretamente no adoecimento e morte destas populações, como nos relata a entrevistada indígena da etnia Shuar:

O rio está contaminado pelos derrames dos poços petroleiros. A 250 metros da minha casa, está um poço petroleiro. Minha mãe e meu pai morreram de câncer e eu te pergunto: o que fazer? Não há como evitar; contaminam tudo. A minha mãe dizia: me dói a cabeça, me sinto mal com este cheiro de petróleo, me sinto mal. Adoeceu e morreu por causa do petróleo. Para nós o que sobra são as doenças. Eu sempre trabalhei cultivando mandioca, milho e tenho minhas galinhas. Eu pescava no rio... Agora é difícil. Não podemos pescar porque o rio está contaminado (informação verbal, grifo nosso) ${ }^{30}$.

A maioria dos entrevistados das comunidades, que foram e são afetados pelas atividades de exploração petroleira, tem a percepção de que estas dinâmicas extrativistas destroem seus territórios e afetam, de forma quase irreversível, suas formas de vida. Tanto que muitos afirmaram: "não queremos mais exploração petroleira em nossos territórios". Ilustramos esta situação destacando a percepção da liderança Waorani que nos disse:

O petróleo não trouxe desenvolvimento para os Waorani. Só nos trouxe vazamentos de óleo e doenças". Perfurar a floresta pode não só causar danos e contaminação do ecossistema da Amazônia através de vazamentos de óleo e despejos de lixo tóxico, mas a construção de estradas para acessar essas regiões remotas pode estimular o desenvolvimento de outras indústrias, como

\footnotetext{
${ }^{28}$ Entrevista concedida por M.B Entrevista I [Jul. 2017]. Entrevistador: autora. Porto Alegre, 2017. 1 arquivo .mp3 (60 min.). M. B. Geógrafo, integrante do coletivo de geógrafos críticos. Tradução da autora. ${ }^{29}$ Entrevista concedida por A.A Entrevista VII [Set. 2017]. Entrevistador: autora. Quito, 2017. 1 arquivo .mp3 (120 min.). A. A. Economista, Ex-ministro de Energia do governo Rafael Correa, responsável pela Iniciativa Yasuni-ITT. Tradução da autora.

${ }^{30}$ Entrevista concedida por M.S Entrevista IX [Out. 2017]. Entrevistador: autora. Coca, 2017. 1 arquivo .mp3 (60 min.). M. S. Indígena, da etnia Shuar. Tradução da autora.
} 
mineração e agricultura, o que poderia levar ao tipo de desmatamento massivo que dizima nosso povo e a Amazônia (informação verbal) ${ }^{31}$.

$\mathrm{Na}$ entrevista que realizamos com um dos indígenas que trabalha na fundação Alejandro Labaka, o mesmo comentou que: "depois de 26 anos de litigio, os habitantes prejudicados pelas atividades da Texaco seguem lutando para reivindicar seus direitos e os danos ambientais causados pela petroleira seguem ali" (informação verbal) ${ }^{32}$. Existem muitas áreas contaminadas por diversas empresas petroleiras em diversos pontos da Amazônia. As empresas petroleiras utilizam todo seu poderio para sair ilesas. Ainda que vários processos tenham conduzido as mesmas ao banco dos réus, é muito difícil condená-las. Tem-se o emblemático caso da Chevron-Texaco que até hoje não restituiu minimamente os prejuízos e a destruição causados ao território e às populações.

\section{A convivência na Amazônia e as múltiplas faces do Sumak Kawsay/Buen Vivir na comunidade}

O conceito de Sumak Kawsay/Buen Vivir, desde sua notoriedade a partir das constituições Boliviana e Equatoriana, foi alvo de pesquisas no âmbito acadêmico e recebeu muitos questionamentos. Uma das tantas discussões acadêmicas que surgem em torno do Sumak Kawsay/Buen Vivir é sobre este ser uma tradição inventada ${ }^{33}$ para servir como uma plataforma política aos governos progressistas da Bolívia e do Equador ou ainda representar uma visão essencializada das formas de vida do mundo indígena andino.

Sobre isso, gostaríamos de trazer outra perspectiva, uma narrativa vivencial, a partir da pesquisa de campo e da convivência com grupos indígenas na América Latina ${ }^{34}$. Existem muitas especificidades e diferenças entre as tantas etnias indígenas (14 nacionalidades) no Equador. Então, nosso exercício é de nos debruçarmos sobre as práticas que remetem aos aspectos do Sumak Kawsay/Buen Vivir que observamos na convivência que tivemos com estes grupos.

A perspectiva decolonial é uma opção não somente teórica e, justamente por essa escolha, acreditamos ser importante discutir algumas categorias a partir da fala dos atores indígenas, não nos remetendo somente aos intelectuais e às metanarrativas sobre a temática do Sumak Kawsay/Buen Vivir. Mais do que pensar, a partir das discussões

\footnotetext{
31 Entrevista concedida por P.B. Entrevista VI [Out. 2017]. Entrevistador: autora. Coca, 2017. 1 arquivo.mp3 (110 min.). P.B. Liderança Waorani, representante da Associação OME Yasuni, vive na comunidade de Bameno em Pastaza, Região Amazônica Equatoriana (RAE). Tradução da autora.

${ }^{32}$ Entrevista concedida por W.H Entrevista V [Out. 2017]. Entrevistador: autora. Coca, 2017. 1 arquivo .mp3 (60 min.). W. H. Indígena, assessor na Fundação Alejandro Labaka. Tradução da autora.

${ }^{33}$ Esta expressão já foi discutida no capítulo 5 deste estudo.

${ }^{34}$ A experiência vivencial que tivemos com movimentos indígenas e comunitários no contexto de países como Equador, Bolívia, Peru e Chile a partir do ano 2009.
} 
que têm se estabelecido em diferentes âmbitos acadêmicos, nos interessa refletir desde nossa vivência com as populações indígenas, sobretudo, as do altiplano andino e da Amazônia equatoriana. Buscamos trazer elementos do Sumak Kawsay/Buen Vivir presentes no mundo vivido destas populações e que apesar de toda violência dos processos da colonialidade/neocolonialidade de poder, resistiram no tempo. Queremos dar destaque a nossa vivência durante a marcha indígena e também o acompanhamento da formação em turismo comunitário, junto à Fundação Alejandro Labaka, buscando refletir sobre processos de resistência às dinâmicas extrativistas, para pensar algumas expressões do Sumak Kawsay na comunidade.

A convivência com grupos indígenas durante a marcha, como percebida nas Figuras 2 e 3 nos permite discutir algumas relacionadades/racionalidades dos grupos indígenas. Como já referido na parte da pesquisa de campo desta tese, acompanhamos a marcha indígena que saiu da cidade de Puyo (capital da província de Pastaza na Região Amazônica Equatoriana) até a capital do Equador, cidade de Quito em outubro de 2017.

Figura 2: Grupos indígenas tocando flauta durante a marcha

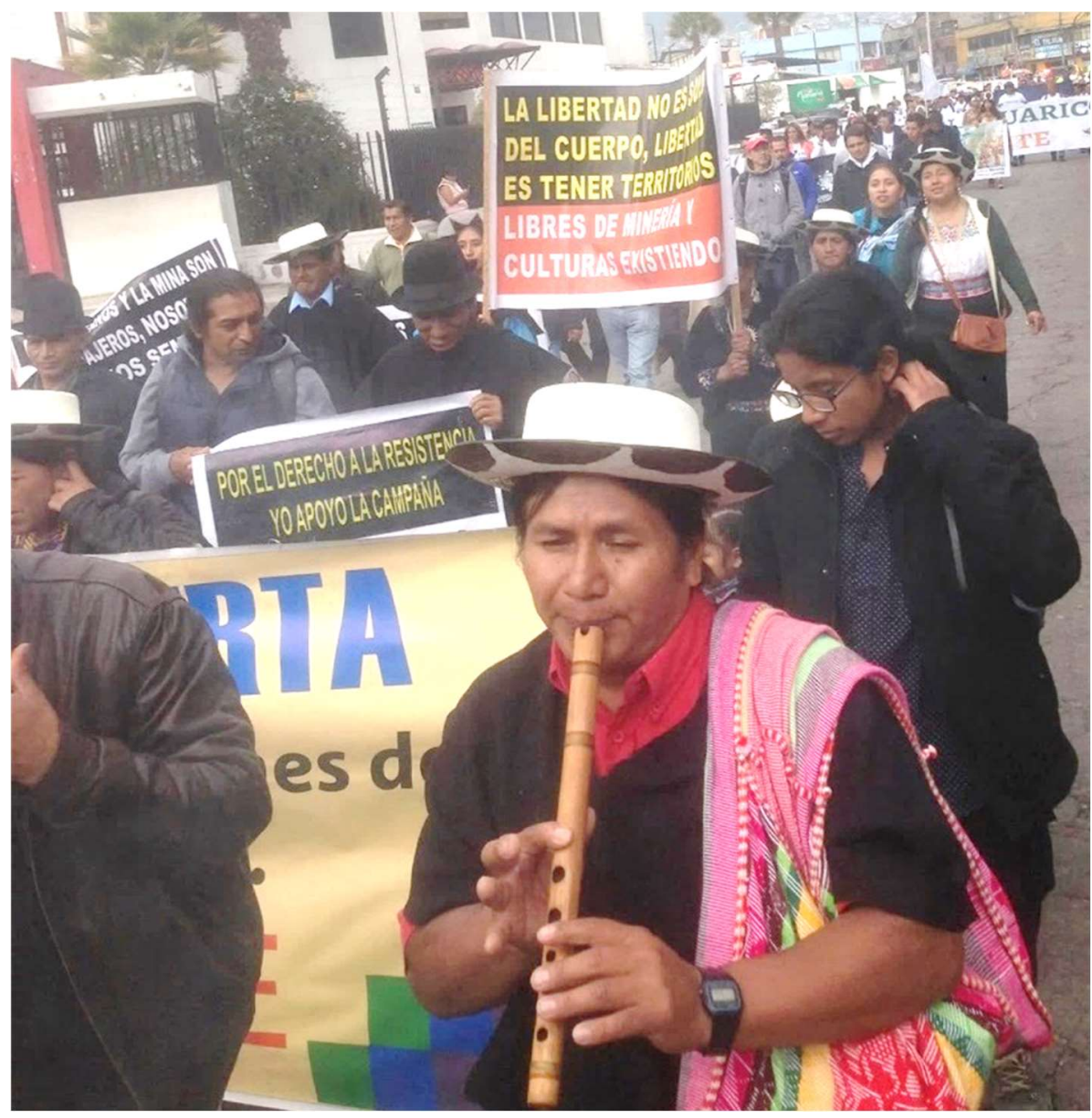

Fonte: Arquivo pessoal da autora. 
A participação na marcha indígena foi um dos tantos momentos dos quais nos foi possível observar aspectos das cosmovisões indígenas do altiplano andino e da Amazônia Equatoriana. Em muitos momentos ficamos em silêncio caminhando, ouvindo e observando o ritmo e as situações que aconteciam a nossa volta.

A marcha era organizada em tempos, tinha os tempos para caminhar e para as paradas que eram para a alimentação e cuidados gerais. Aproveitamos todos os momentos para compreender/apreender as distintas lógicas/relacionalidades/racionalidades implicadas nas situações vivenciadas. Denominamos estes momentos de pedagogia da marcha. Pedagogia porque muitas situações nos propiciaram aprendizados importantes.

$\mathrm{Na}$ marcha indígena tinha água, comida e uma logística de distribuição. Ninguém ficava sem alimento ou sem água. Caso alguém estivesse machucado, era cuidado, era atendido. Os mais velhos eram, quase sempre, os que menos demonstravam cansaço; permaneciam fortes e altivos na caminhada. Enquanto marchávamos por horas, alguns conversavam alegremente, outros cantavam e tocavam instrumentos, como flautas e quenas, outros riam gostosamente de qualquer coisa, aparentemente, sem muita importância. Os espaços na marcha eram distribuídos por etnia. Então, se olhássemos de longe podíamos ver as vestimentas tradicionais de cada grupo na marcha.

Havia uma lógica que não era dita, mas era implícita: o alimento, a comida era de todos e para todos. É algo muito impressionante porque todos organizam, trazem alimentos e é para ser compartilhado. Compartilhar é quase mais importante do que comer. Causa certa surpresa porque se tem a garantia de que será alimentado. Todos são convidados, inclusive se você não levou nada para compartilhar. Um dia um indígena Waorani comentou comigo que existe uma intencionalidade na alimentação: não é só o estômago que recebe o alimento, mas todo corpo (temos, então, presente a ideia de inseparabilidade da totalidade do corpo). Nas palavras do entrevistado:

Quando compartilhamos os alimentos, são também os sentimentos que são compartilhados. Não existe a separação entre o que intenciono e o que estou servindo. Por isso, existe um ritual para preparar, compartilhar e agradecer o alimento porque o que estamos comendo é carregado de intencionalidade, se alimenta a totalidade do corpo (que não é separado do espírito) (informação verbal) $)^{35}$.

Na cultura ocidental não percebemos que não é somente o corpo físico, orgânico que é alimentado, mas uma totalidade. Além disto, como

\footnotetext{
35 Entrevista concedida por C. O. Entrevista VIII [Out. 2017]. Entrevistador: autora. Coca, 2017. 1 arquivo.mp3 (110 min.). C. O. Indígena Waorani que vive no Parque Nacional Yasuni, Região Amazônica Equatoriana (RAE). Tradução da autora.
} 
refere 0 pensador Boliviano Rafael Bautista $^{36}$, existe uma intencionalidade/energia quando cozinhamos, quando preparamos o alimento. Podemos pensar como é um almoço preparado por nossa mãe e como nos nutrirmos com alimentos preparados em um restaurante. Quais intencionalidades existem nestes dois casos? O alimento preparado pela mãe tem seu carinho, sua intencionalidade de nos nutrir. Então qual a intencionalidade de uma comida comprada na rua, preparada por um estranho que nem nos conhece? $O$ ato de compartilhar alimentos que percebemos na marcha, conforme Figura 3, é um ritual presente em outras comunidades.

Figura 3: compartilhamento dos alimentos em atividade comunitária dos povos

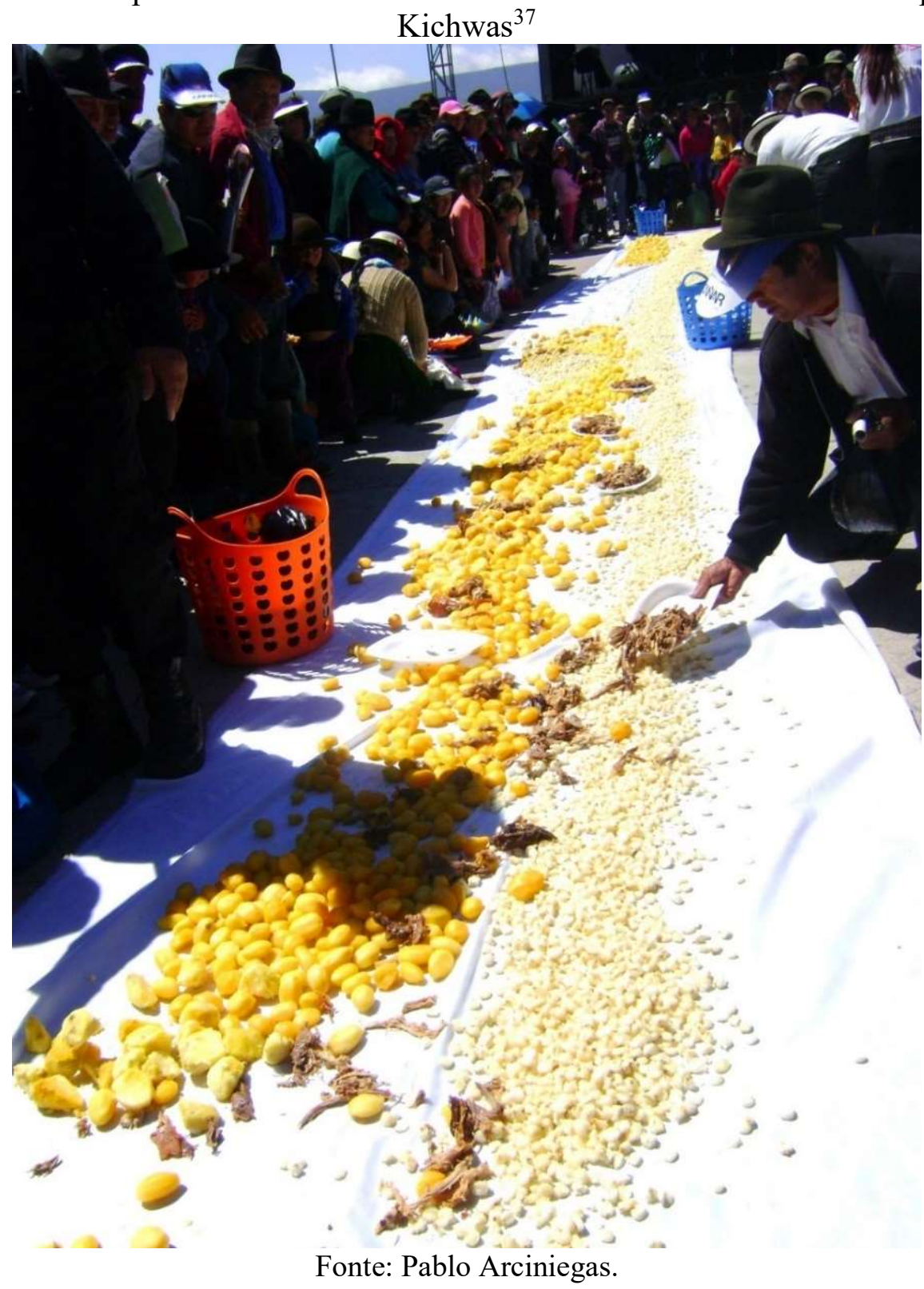

\footnotetext{
${ }^{36}$ Rafael Baustista discute esta e outras ideias no espaço de formação denominado "Talleres para la descolonizacion".

${ }^{37}$ Arquivo pessoal do Sociólogo Pablo Arciniegas (comunidade no interior da província de Azuay/ Equador).
} 
Observamos em muitos momentos um forte sentimento de pertencimento ao grupo, à grande família, eles dizem: somos todos família (assim mesmo, no singular, porque é uma só família). Vejam bem, neste caso, a família é conformada por uma extensa rede de relações e de parentesco. O sentimento de solidariedade e coesão expressa-se no compartilhamento de água, de alimentos e de cuidados com todos. Ainda que sejam de diferentes etnias com suas especificidades, eles se tratam por "irmãos". Isto nos remete a uma relação contida na ideia de Ayllu que não é somente uma organização da sociedade de seres humanos, mas é um sistema de organização da vida de todos os seres, de tudo que existe, de tudo que flui em equilíbrio no planeta ou Mãe Terra (CHOQUEHUANCA, 2020).

Nas casas Waoranis, conforme Figura 4, vivem de cinco a seis famílias sob a autoridade de um ancião que pode ser uma mulher ou homem. As cantigas são muito presentes na vida dos povos Waoranis. Um dos entrevistados indígenas, com quem convivemos, às vezes parava de conversar comigo e começava a cantar. Certo dia ele comentou: "nós cantamos para ter sorte na caça, para agradecer, bom, cantamos para quase tudo" (informação verbal) ${ }^{38}$.

Figura 4: Casa tradicional da etnia Waorani na Amazônia

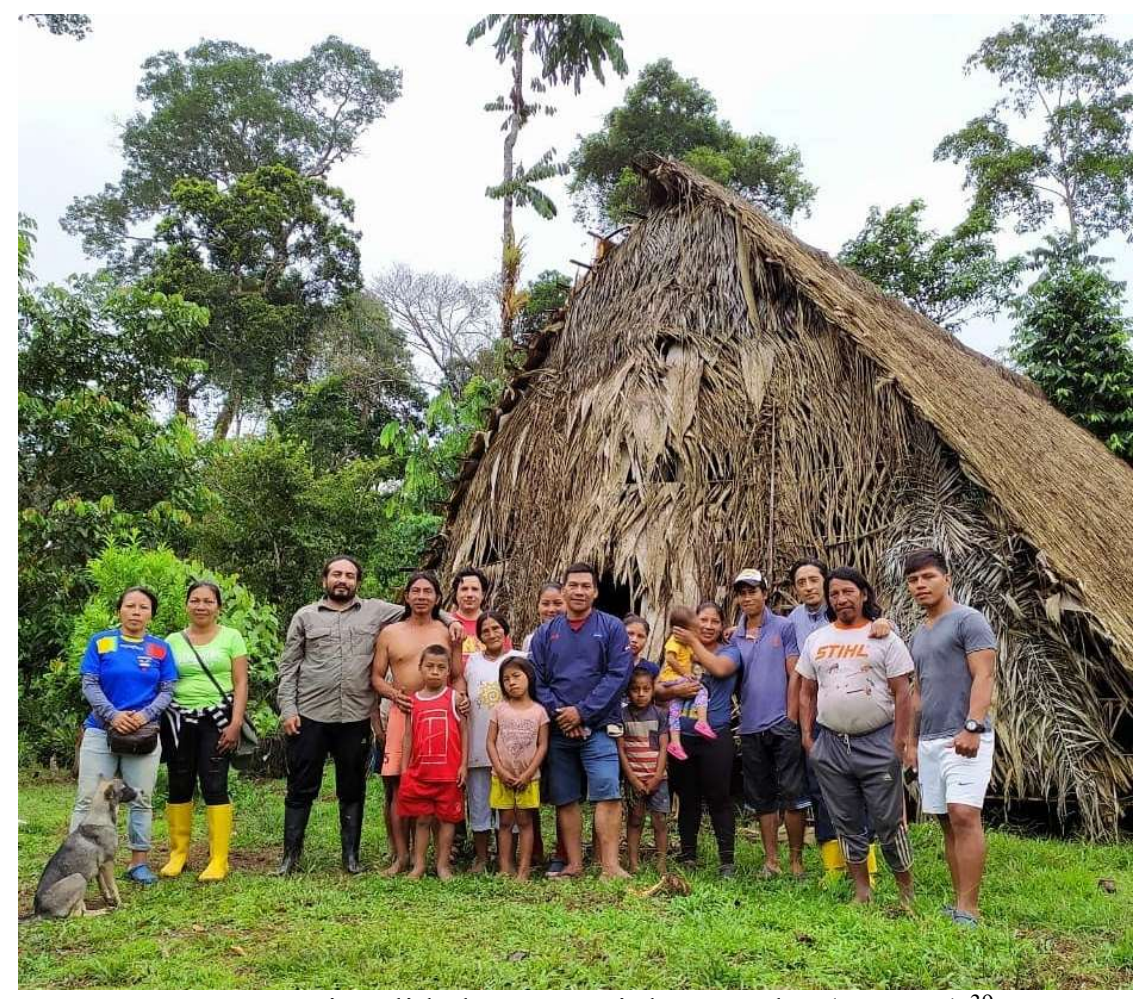

Fonte: Nacionalidade Waorani do Equador (NAWE) ${ }^{39}$

\footnotetext{
38 Entrevista concedida por C. O. Entrevista VIII [Out. 2017]. Entrevistador: autora. Coca, 2017. 1 arquivo.mp3 (110 min.). C. O. Indígena Waorani que vive no Parque Nacional Yasuni, Região Amazônica Equatoriana (RAE). Tradução da autora.

${ }^{39}$ Esta foto e outras foram gentilmente cedidas pela Nacionalidade Waorani do Equador (NAWE) para este trabalho. Disponível em: https://www.facebook.com/nawewao2019. Acesso em: set de 2020.
} 
A formação política se dá em todos os espaços: seja nas conversas entre todos, na ação, na organização igualitárias das tarefas. Na marcha não precisava escala: todos trabalhavam para organizar a comida, acomodar os mais idosos e as crianças. Tínhamos observado estas práticas no Movimento dos Trabalhadores Rurais Sem Terra (MST) ${ }^{40}$ no Brasil, mas no caso deste movimento se faz necessário o aprendizado de uma rigorosa disciplina.

Em muitos momentos nos foi possível observar que não existe uma hierarquia para a organização do trabalho. Há uma forma diferenciada de divisão do trabalho. É como se o trabalho pertencesse a todos e, desta forma, todos se comprometessem. Não existe também uma tarefa que possa ser considerada mais importante que outra. Durante minha convivência com diversos grupos não observei graves contendas.

Esta pedagogia do aprender fazendo é algo que os zapatistas também dizem como mandar/obedecendo. É interessante porque é aprender na práxis, no vivencial; aprender com o outro, aprender com os mais velhos. Realizar as tarefas juntos se constitui como um aprendizado e uma troca simbólica muito importante. É aprender "com" o outro e não "do" outro. Já na educação ocidental, alguém ensina e alguém aprende. A maioria das instituições educativas ainda funciona sob estes parâmetros.

O trato com as crianças é outro aspecto muito interessante. A educação - a qual não é chamada de educação, mas de orientação - é realizada pelo exemplo. É no fazer que se orientam as crianças. Eu nunca ouvi um indígena de qualquer etnia gritar com os seus filhos, ou gritar com as crianças da comunidade. Muito importante valorizar a abordagem deste entrevistado indígena, quando fala sobre como se educam as crianças. Nestas linhas percebemos uma importante filosofia de vida:

Nossas crianças não recebem educação, recebem orientação. Não aprendem a ser vencedores porque para uns vencerem, outros têm de perder. Aprendem a partilhar o lugar onde vivem e o que tem para comer. Tem o exemplo de uma vida onde o indivíduo conta menos do que o coletivo. Este é o mistério indígena, um legado que passa de geração para geração. O que as nossas crianças aprendem desde cedo é a pôr o coração no ritmo da terra (informação verbal) ${ }^{41}$.

As crianças são de responsabilidade de todos, outro ponto que merece atenção: como todos somos família, o filho do "outro" deve ser tão bem cuidado, querido e respeitado quanto o "meu".

\footnotetext{
40 Trabalhei por muitos anos com o Movimento dos Trabalhadores Rurais Sem Terra (MST), por isso conheço muitas dinâmicas internas deste movimento.

41 Entrevista concedida por B. I. Entrevista IV [Out. 2017]. Entrevistador: autora. Otavalo, 2017. 1 arquivo.mp3 (90 min.). B.I. Indígena Kichwa, liderança da CONAIE. Doutor em história. Tradução da autora.
} 
Nós nos ajudamos entre a comunidade, fazemos a minga, cuidamos uns dos filhos dos outros. Agora faz uns anos que constituímos um fundo comum, juntamos dinheiro dos pais de família para emergências e também para podermos fazer algum programa de família, sair da comunidade junto com nossos filhos (informação verbal) ${ }^{42}$.

Eles riam de nossa preocupação com as crianças. Como uma mãe bastante protetora e acostumada a cuidar sozinha da filha, custava compreender que todos cuidavam de todas as crianças. E também que as crianças aprendiam a se cuidar desde muito pequenas.

Certo dia um pequenino com menos de dois anos estava subindo a escada e eu, muito temerosa por sua segurança, o peguei no colo e o retirei dali, levando-o para a planta baixa da casa, obviamente com medo que ele caísse e se machucasse. Ao chegar na planta baixa e soltá-lo no chão, sua mãe me observava e ria de mim, sem disfarçar; eu não entendia e tentei argumentar que era perigoso para a criança, ela disse que ele não cairia, pois era acostumado a subir nas árvores, desde que tinha menos de um ano. O que para mim ainda não era motivo suficiente para deixá-lo livremente subir as escadas (DIARIO DE CAMPO DA AUTORA, AMAZÔNIA EQUATORIANA, 2017).

Sempre observávamos várias coisas e anotávamos. Certo dia, um indígena jovem, com quem já havíamos conversado outras vezes, nos perguntou: "o que você tanto anota neste caderno? A pergunta nos surpreendeu e refletimos como explicar o que apontávamos. O que poderíamos dizer? Dizer que as anotações eram sobre eles ou sobre as impressões que tínhamos das coisas que eles faziam? Tal situação causonos desconforto, uma sensação de impotência nos invadiu. Não queríamos causar a impressão de que os percebíamos como algo exótico ou diferente. Percebendo nosso embaraço para responder, ele calmamente apenas sorriu e disse que não importava.

Depois deste episódio, sentíamos certa apreensão. Não queríamos que eles se sentissem vigiados com nossa presença, mas como evitar isso? Como é difícil desconstruir esta relação sujeito-objeto na pesquisa, sobretudo quando as diferenças são dadas a priori, em universos simbólicos distintos e, principalmente, quando não dispomos de tempo necessário para ter uma relação mais próxima e profunda.

Ilustramos parte das cosmovisões presente nas nacionalidades indígenas amazônicas Waoranis através de um evento atual, do ano de 2020, o qual, portanto, não integra a pesquisa de campo. No entanto, o

\footnotetext{
42 Entrevista concedida por M. S Entrevista IX [Out. 2017]. Entrevistador: autora. Coca, 2017. 1 arquivo.mp3 (60 min.). M. S. Indígena, da etnia Shuar. Tradução da autora.
} 
que chama atenção é forma pela qual as nacionalidades Waoranis conduziram esta situação.

A revista Time $100^{43}$ reconheceu a indígena Waorani Nemonte Nenquimo, presidente dos povos Waorani de Pastaza, como uma das cem personalidades mais influentes do mundo no ano de 2020. O reconhecimento da revista deve-se à luta destes povos (do território de Pastaza) na defesa da floresta amazônica contra as indústrias e as companhias de petróleo. A Nacionalidade Waorani do Equador (NAWE) lançou no mesmo dia uma carta. Abaixo transcrevemos parte do documento:

\begin{abstract}
O reconhecimento da revista Time para nossa companheira Nemonte Nenquimo e para todo nosso povo é uma grande honra. Sabemos que no mundo ocidental tudo se baseia no individualismo (por isso dão reconhecimento a indivíduos), mas para nós não há luta, nem saúde, nem alegria, nem futuro sem família, sem o povo e sem nossa selva. Dedicamos este reconhecimento a nossos ancestrais, que morreram defendendo a vida, a nossos anciãos (Pikenani), as mulheres lutadoras e aos bebês que, todavia, ainda estão nas redes, mas que logo serão os herdeiros desta selva ${ }^{44}$.
\end{abstract}

Neste excerto se apresentam elementos que merecem reflexão. Primeiro, atentar para a ideia de indivíduo, tão cara a modernidade ocidental que sustenta justamente uma subjetividade "egocentrada", da qual nascem as noções de competição, de ganância e de não pertencimento. Interessante observar que o documento traz elementos que ouvimos repetidas vezes de diferentes etnias indígenas, "não somos nada sem a família, sem a comunidade e sem a selva". Temos presente uma noção que extrapola a ideia de indivíduo, porque somos alguém na medida em que pertencemos à (grande) família e à selva. Portanto, a identidade é relacional, numa complexa teia de inter-relações de família e parentesco, que não é somente entre humanos, mas abarca outras formas de vida.

\title{
Turismo comunitário: uma alternativa econômica voltada ao Sumak Kawsay
}

Uma vivencia muito interessante foram os dias em que acompanhamos o curso de turismo comunitário junto à Fundação

\footnotetext{
${ }^{43}$ A notícia foi disponibilizada no dia 24 de setembro de 2020. Disponível em: $<$ time.com/collection/100most-influential-people-2020/5888337/nemonte-

nenquimo/?fbclid=iwar0bdrxoxve_rb0ugdkshhxou4oonsgykxauimexkvazmkmqj0opyuvufvw $>$ acesso em: set de 2020 .

44 Documento na integra se encontra na página. Disponível em: https://www.facebook.com/nawewao2019. Acesso em: set de 2020. Tradução da autora.
} 
Alejandro Labaka na Região Amazônica do Equador. O curso teve duração de cinco dias. Participaram 40 indígenas (havia bastante jovens) das etnias Waorani, Shuar, Ashuar, e Kichwas amazônicos, de dez comunidades da Amazônia Equatoriana, conforme observado na Figura 5. Há aspectos que merecem destaque neste curso de turismo ecológico.

Figura 5: Turma do curso de turismo ecológico comunitário

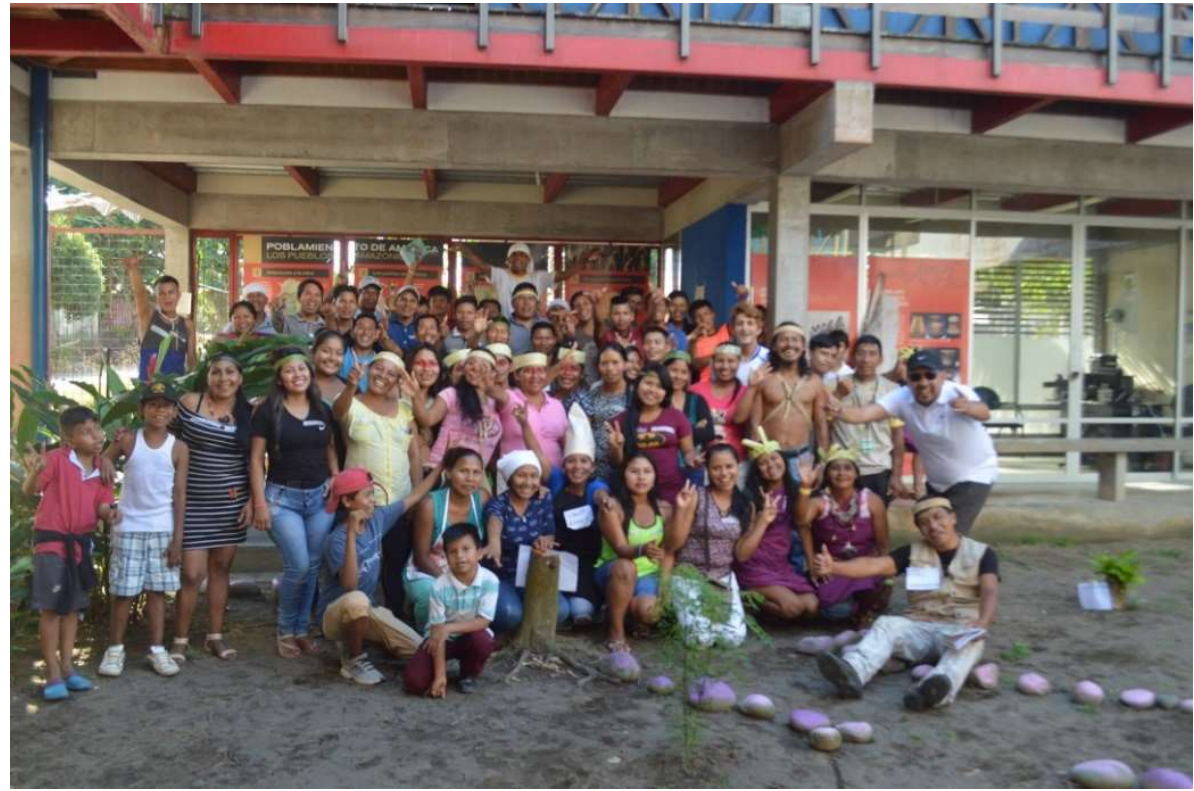

Fonte: Arquivo pessoal da autora.

O curso de formação em turismo comunitário, de 40 horas, se destinava a capacitar os indígenas para desenvolver empreendimentos em suas comunidades. Acompanhamos o curso todos os dias. Tinha uma dinâmica muito interessante. O professor conhecia muito bem as comunidades e trouxe vivências consideradas bem-sucedidas de outras comunidades que já possuíam estes projetos.

$O$ instrutor/professor do curso era um grande entusiasta da proposta de turismo comunitário. O fato de conhecer as comunidades indígenas fazia com que tivesse muita didática ao explicar os conteúdos. Inclusive, ele falava algumas palavras em Kichwa e Waorani.

Percebemos o interesse pelas iniciativas de turismo comunitário, sobretudo, dos mais jovens e das mulheres. Muitos jovens das comunidades também têm projetos e trabalhos na área da fotografia e produção de vídeos - produzem imagens para documentários (em sua maioria, internacionais) sobre o território. Existem também cursos de guia turístico para os indígenas e muitos falam fluentemente outros idiomas como inglês, francês e italiano.

Na Figura 6, um grupo de mulheres jovens indígenas discute como organizar um empreendimento na comunidade a partir dos conhecimentos e orientações obtidos no curso. Enquanto na Figura 7, observa-se grupos indígenas apresentando os atrativos das suas comunidades para o turismo comunitário. 
Figura 6: Mulheres indígenas jovens participantes do curso de turismo comunitário

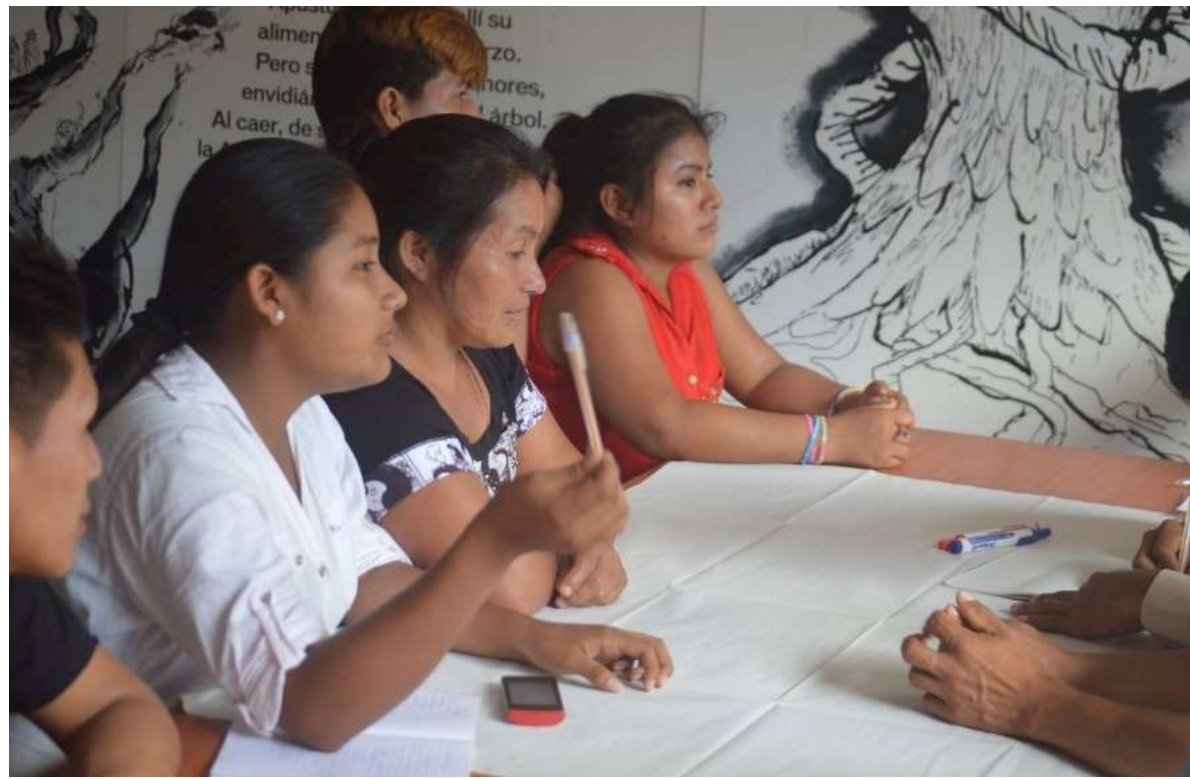

Fonte: Arquivo pessoal da autora.

Figura 7: Grupo indígena apresenta os atrativos da comunidade para o turismo comunitário voltado ao público infantil

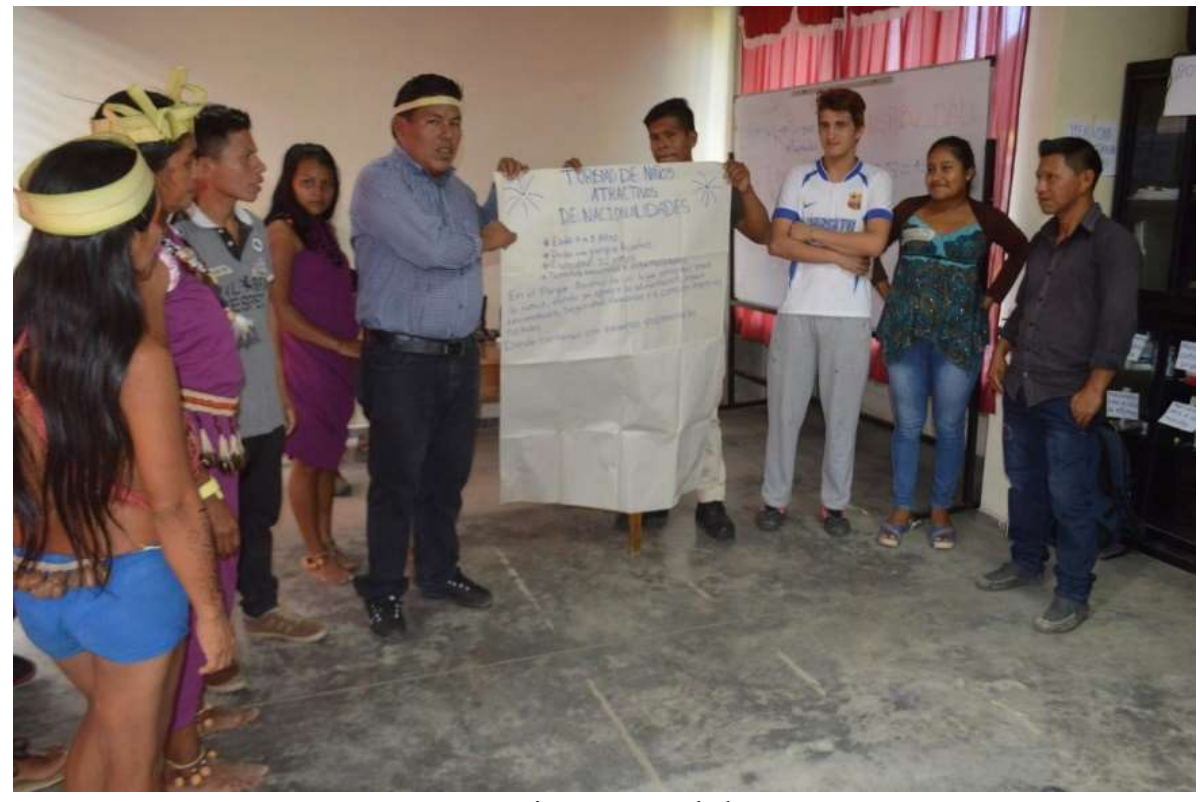

Fonte: Arquivo pessoal da autora.

Muitos indígenas referiram que queriam trabalhar com projetos que não agredissem a selva. É ilustrativa a entrevista desta liderança Waorani:

Nós pensamos em preservar a selva (ömædë). Alguns trabalham com um turismo comunitário que preserva toda vida, mas queremos que nos respeitem porque somos mais antigos que os próprios equatorianos. Para nós, a palavra é uma só: não mais petróleo, queremos manter nossa tradição, idioma e forma de viver, esta é 
a nossa mensagem. A única forma que queremos de desenvolver são as visitas de turistas, porque eles vêm, visitam, conhecem a gente, nossa forma de vida e não danificam nossa Mãe Terra. Este é o desenvolvimento para o Buen Vivir. Agora o petróleo só nos traz prejuízo e aí eles vão embora e deixam só destruição e contaminação para nós. Para mim o Parque Nacional Yasuni está muito explorado, você viu? Já está cheio de blocos petroleiros. Então qual é a proteção para o nosso território? Para nós é muito triste, os povos não são respeitados. As ONG's internacionais também às vezes querem nos explorar, querem nos dizer o que temos que fazer. Os povos em isolamento vão ter conflitos e vão ser mortos. Por isso a única saída é acabar com a exploração petroleira em todo Parque Nacional Yasuní (PNY). Para nós o Buen Vivir é boa vida e como tenho boa vida? Se estou na minha casa, se estou na selva, quero ver a selva, quero respirar o ar puro e quero ouvir os pássaros cantar (informação verbal, grifo nosso) ${ }^{45}$.

Esta entrevista representa como os indígenas percebem as contradições entre as lógicas/dinâmicas de um capitalismo predatório que destrói a natureza e não reverte em nenhum benefício para eles, mas, ao contrário, representa a destruição e o extermínio. E, por outro lado, como se configuram as possibilidades de um desenvolvimento voltado para o Sumak Kawsay/Buen Vivir destas comunidades, o qual visa respeitar as culturas, as filosofias e as formas de viver destes povos.

Os empreendimentos de turismo comunitário podem representar uma das possibilidades de desenvolvimento voltado para o Sumak Kawsay. Sobre este ponto gostaríamos de retomar a entrevista acima e também dar eco ao que vivenciamos com os povos indígenas. Parte dos dilemas e contradições sobre a Iniciativa Yasuni-ITT, teve como argumento a necessidade de recursos para combater a "pobreza" na Amazônia. A questão é que existem outras formas de produzir ingressos que revertam para estas populações, sem a exploração direta e intensiva dos "recursos naturais".

Então, aqui temos um efeito demonstrativo de que o modelo extrativista que é capitalista/moderno/colonial/patriarcal poderia dar lugar a uma pluralidade de propostas. Existem iniciativas oriundas das próprias comunidades baseadas em outras racionalidades, que respeitam as diversas dinâmicas que se dão no território e as formas de vida destes povos, as quais poderiam receber apoio institucional do governo.

Existem muitos empreendimentos na Amazônia voltados para o turismo comunitário. A ideia é propiciar aos turistas uma vivência que se aproxime do dia-a-dia das comunidades indígenas. As comunidades organizam um complexo turístico que inclui toda logística, desde o

\footnotetext{
45 Entrevista concedida por P. B. Entrevista VI. [Out. 2017]. Entrevistador: autora. Coca, 2017. 1 arquivo.mp3 (110 min.). P.B. é representante da Associação OME Yasuni, vive na comunidade de Bameno em Pastaza, Região Amazônica Equatoriana (RAE). Tradução da autora.
} 
trajeto para chegar à comunidade e compreende todo planejamento para a estadia.

Os turistas chegam para permanecer dias nas comunidades, nas casas tradicionais e podem experimentar a culinária, as bebidas, as vestimentas, as pinturas corporais, as danças, os rituais. Há comunidades que oferecem atividades diversificadas, como passeios nos rios (que podem ser em canoas ou mergulhos diurnos e noturnos) e trilhas na selva (caminhadas com a observação de animais exóticos) e até a atividade de pesca e caça (que é menos comum).

Eu faço turismo ecológico porque esta atividade não agride e destrói a natureza. Levo as pessoas para conhecer e valorizar a selva. Além disso, eu posso gerar consciência sobre a importância de proteger nossa selva, nossa casa. Se destruirmos a selva, nos destruiremos. Então, temos nossa fundação que organiza o turismo e que faz muitas coisas pela comunidade. Também recebe voluntários do mundo inteiro para conhecer nossos costumes, nossas formas de vida, e vêm para cá médicos que querem conhecer nossa medicina ancestral (informação verbal) ${ }^{46}$.

Interessante observar que o turismo comunitário é uma das tantas formas de auto-gestão e organização alternativa de renda para estas populações sem que, para isso, se necessite destruir a selva. Mereceriam certamente mais atenção estas experiências, uma vez que são consonantes com as formas de vida comunitária destes povos e respeitam suas cosmovisões. Sem contar que existe a gestão direta dos recursos, o que representa significativas melhorias na vida destas populações.

Uma experiência muito importante que, de alguma maneira também se relaciona com a Iniciativa Yasuni-ITT e com o Buen Vivir, é a do grupo de indígenas Kichwas da região de Sarayaku na região Amazônica. A proposta de resistência deste grupo se chama "Kawsak Sacha/Selva Viviente" e visa ser uma resposta propositiva e afirmativa ante a exploração de petróleo nesta região. Esta ação dos povos Kichwas de Sarayaku pode ser compreendida como a necessidade de tornar efetivos os direitos da natureza e dos povos originários previsto na Constituição do Equador de 2008.

A comunidade de Sarayaku no lançamento oficial de sua proposta na cidade de Quito, no ano de 2018 , declarou seu território como área de proteção livre de exploração extrativa, petroleira, mineira ou madeireira. Enfatizando que era uma demanda pelo reconhecimento jurídico-político da existência de outros seres - espíritos, árvores, cascatas, Pachamama - como vivos e conscientes igual aos humanos, exigindo respeito às suas formas de vida (cosmopolíticas).

\footnotetext{
${ }^{46}$ Entrevista concedida por F. C. Entrevista X [Out. 2017]. Entrevistador: autora. PASTAZA, 2017. 1 arquivo .mp3 (60 min.). F.C. Indígena Kichwa amazônico, guia turístico, integrante da organização Amauta Ecotur. Tradução da autora.
} 
A proposta da qual são protagonistas os povos de Sarayaku é parte de uma longa trajetória de luta e resistência destes povos aos processos extrativistas, sobretudo, os petroleiros. Além de se constituir como um novo marco na elaboração de conceitos e propostas que estes povos apresentam ao Estado e as organizações internacionais, como um passo à frente nas resistências que se constroem desde estes povos e territórios.

Igualmente importante é visibilizar a resistência dos povos Waoranis que, através da luta, vide Figura 8, 9 e 10, conseguiram frear a exploração de petróleo em seu território (no bloco 22) no Parque Nacional Yasuni (PNY). A mobilização dos jovens e das mulheres possibilitou a realização de um mapeamento comunitário do território e, assim, levaram o Estado a instâncias judiciais. Um dos argumentos foi que houve a manipulação e engano por parte do governo Equatoriano na consulta livre, prévia e informada (CLPI) sobre os possíveis impactos da exploração petroleira no território.

Figura 8: Mulheres da etnia Waorani protestando pela defesa dos territórios

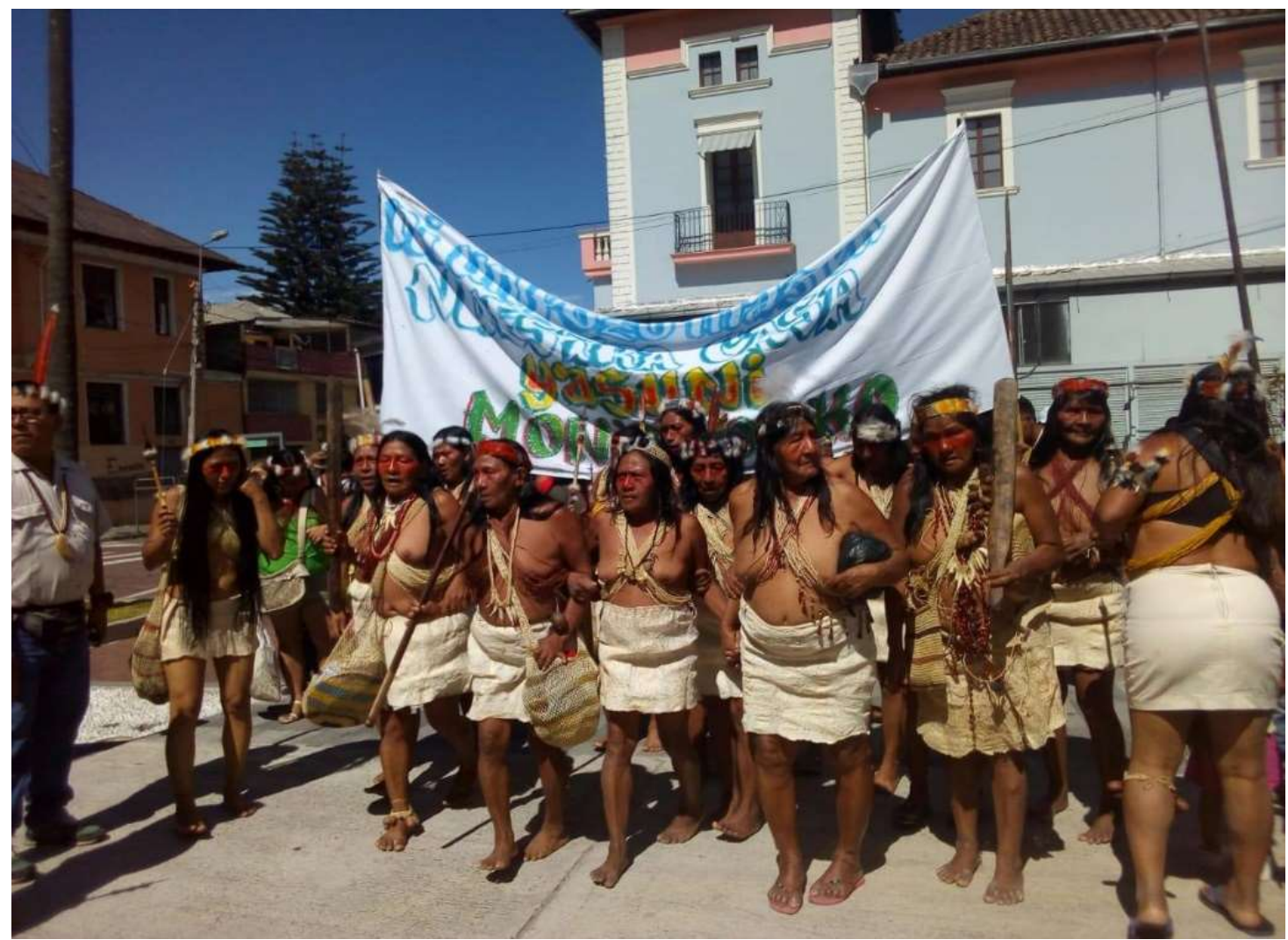

Fonte: Nacionalidade Waorani do Equador (NAWE). 
Figura 9: Audiência pública dos povos da etnia Waorani pela defesa do seu território

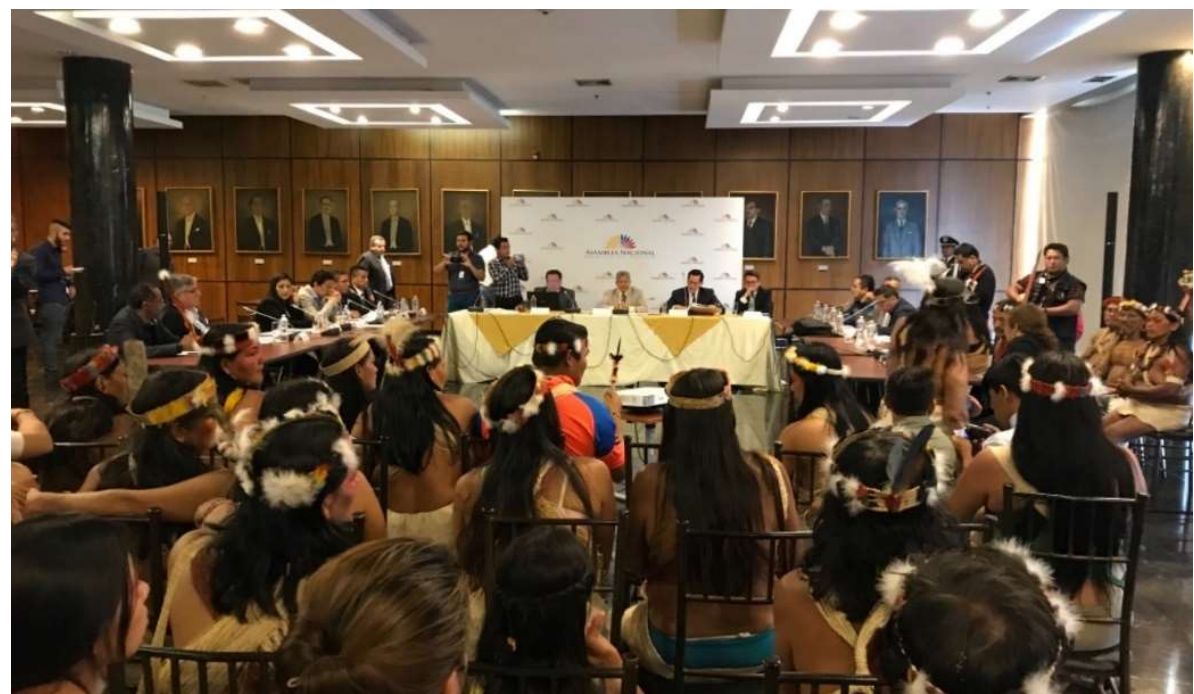

Fonte: Nacionalidade Waorani do Equador (NAWE)

Figura 10: Povos da etnia Waorani no dia do deferimento do pedido de cessação da exploração petroleira no Bloco 22

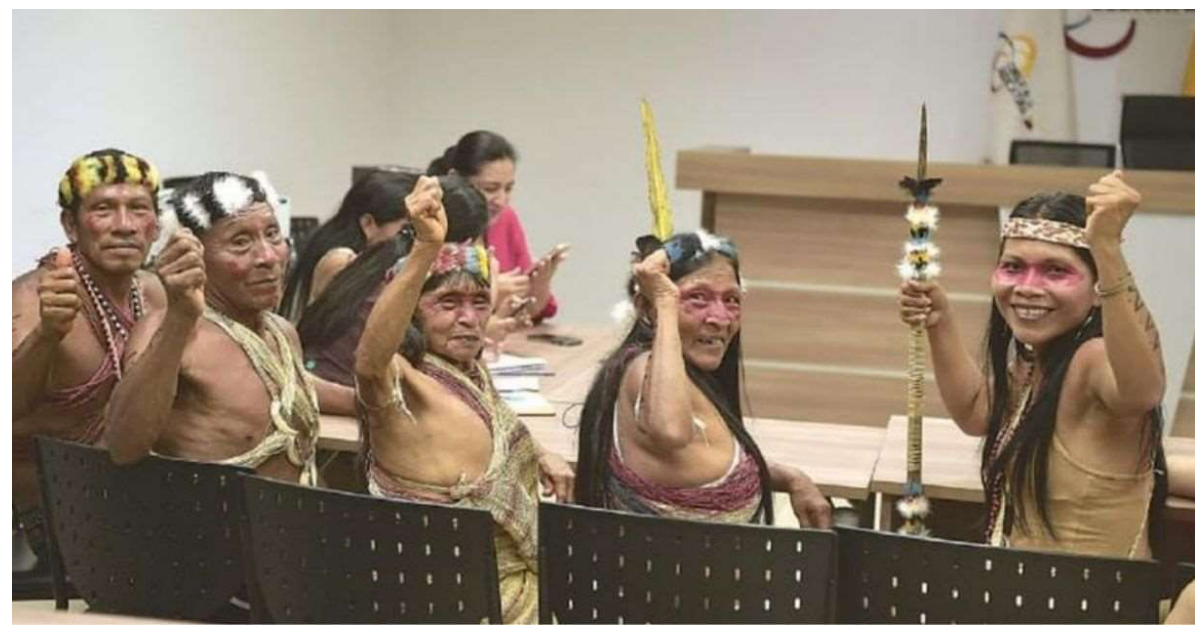

Fonte: Nacionalidade Waorani do Equador (NAWE)

A luta dos povos Waoranis derrotou nos tribunais a exploração petroleira no bloco 22, conseguindo frear as atividades extrativistas e conseguindo desta maneira a preservação deste território. O comentário desta liderança Waorani sintetiza a percepção sobre a questão da autodeterminação sobre seus territórios: "nós é que devemos decidir o que acontece em nossas terras. Nós nunca iremos vender nossa floresta para as companhias de petróleo. O interesse do governo pelo petróleo não é mais valioso do que nossos direitos, nossas florestas, nossas vidas" (informação verbal) ${ }^{47}$.

\footnotetext{
47 Entrevista concedida por P. B. Entrevista VI. [Out. 2017]. Entrevistador: autora. Coca, 2017. 1 arquivo.mp3 (110 min.). P.B. é representante da Associação OME Yasuni, vive na comunidade de Bameno em Pastaza, Região Amazônica Equatoriana (RAE). Tradução da autora.
} 
Temos presente, neste relato, a ideia de que as vidas destes povos valem mais que o petróleo. No entanto, temos percebido uma inversão destes valores através das práticas exploratórias e destrutivas que se dão nestes territórios. É possível saber, por exemplo, que jamais se ouvirão novamente os cantos dos povos Tetetes e Sansahuari e que tantos outros cantos correm risco de desaparição, sem se sentir tocado, enternecido, provocado, implicado por estas situações? Se isso não nos toca, creio que perdemos a capacidade de ouvir as batidas do coração da Mãe Terra.

\section{Consideração finais}

Relativamente à violência da "conquista" nos territórios de Abya Yala, precisamos reafirmar e nomear os processos de genocídio, etnocídio e epistemicídio aos quais foram submetidas as populações que aqui viviam. Ao exterminar estas pessoas, destruímos, em parte, estes saberes e conhecimentos milenares. Além disto, condenamo-nas ao esquecimento forçado de suas culturas, tradições e filosofias.

Os povos originários, para além de visões romantizadas, continuam sofrendo com processos genocidas, epistemicidas, além de serem invisíveis para a maioria das pessoas, das instituições, dos Estados-nações. Não se conhece e nem se tem interesse por estes personagens que, por muito tempo, foram apenas sombras disformes na sociedade dos que se denominavam "brancos" e para a maioria dos Estados-nações percebidos como um problema a ser resolvido.

De outra parte, é necessário também questionar certa imagem de um indígena hiper-real, ou aquela percepção idílica presente no imaginário social de que estes povos viviam no paraíso terrestre, numa relação harmônica com a "natureza" e que, por isso, possuem a obrigação implícita de proteger a "natureza". Outra forma de expressar seria o mito do bom selvagem. Este imaginário também produz o encobrimento do outro (DUSSEL, 2007) e traz consigo a negação da condição de contemporaneidade destes personagens que estão vivos no aqui e agora. Desconhecer e menosprezar as especificidades culturais representa a impossibilidade de compreender as dinâmicas históricas, sociais e culturais destes povos nos últimos 500 anos.

Precisamos assumir desde muitas instituições o racismo estrutural herdado e alimentado a partir da "conquista". Necessitamos dar nome, visibilizar estes processos de encobrimento e extermínio. Uma das possibilidades de fazer frente a tais processos é que comecemos por denominá-los, assumi-los e compreendê-los em distintas instituições. A cosmovisão subjacente ao eurocentrismo precisa ser nomeada e enfrentada, uma vez que as pretensões de universalidade e de único conhecimento válido acabam por legitimar o poder do capital e naturalizar os processos sociais, o que impede a possibilidade de pensar na transformação social para além dos limites que impõe o capitalismo (MARAÑóN, 2014).

A civilização capitalista/moderno/eurocêntrica/patriarcal através de múltiplas estratégias coloniza as instituições e também nossa 
subjetividade, a qual se estrutura e se produz e reproduz desde estes paradigmas, parâmetros, valores e pressupostos. Para resistir a tais processos precisamos produzir brechas, fraturas, linhas de fuga que nos permitam decolonizar nossas instituições, nosso imaginário, pois só assim poderemos construir outros mundos possíveis. Parte da decolonialidade poderia residir em transformar e aprofundar os processos para construção de uma democracia radical, que extrapole a mera gestão do Estado, mas propicie a participação de amplos setores (excluídos) da sociedade na construção do Bem Viver (GARCIA LINERA, 2020).

De outra parte, é importante conhecer e reconhecer a importância das cosmovisões dos povos originários. Recordemos que para estas cosmovisões um aspecto importante é o relacional. Não existe a ideia de indivíduo, somos família, somos comunidade, não existe um eu separado dos outros, por isso intersomos; eu sou porque tu és, que também é a filosofia do Ubuntu na África. Creio que a civilização "ocidentalizada" levará ainda alguns anos para compreender o que significa o aspecto espiritual e de interconexão do cosmos, da teia da vida, o qual traz implícito um conteúdo importante de afirmação da vida, sobretudo, da vida comunitária. Os rios, as florestas, outros seres vivos são constituídos da mesma energia e princípio vital que os humanos.

Esta cosmovisão se apresenta incompreensível para a ciência ocidental padrão ou hegemônica porque desde Descartes e Bacon operouse a radical separação entre seres humanos e "natureza", entre sentir e pensar, entre corpo e mente. Esta ciência tem uma metodologia do cogito ergo sum, penso, logo existo, quando a partir das cosmovisões indígenas seria sinto, logo existo. Como nos diz Aleyne Watene ${ }^{48}$, do Povo Maori: "não sei de onde saiu o dito "penso logo existo"; nós não gostamos. Por isso, compartilho o que diz meu povo: pertenço e, portanto, sou". Precisamos compreender e aprender a noção de que pertencemos, que não estamos separados, que somos um pequeno fio que compõe o tecido da vida.

A separação dos humanos com a "natureza" traz como consequência que pensemos nas outras formas de vida como inferiores, tendo, portanto, menor valor que a vida humana. Assim, percebemos a "natureza" de forma utilitária ou, como afirma Grosfoguel (2016, p. 36), "como um meio para um fim". Nossa concepção de que estamos separados da "natureza" é o que, em parte, produz a exploração sem limites dos "recursos naturais", porque não compreendemos, ainda, que nossa vida depende do equilíbrio dos ecossistemas. Estamos vivendo a sexta extinção de espécies em massa do planeta, sem que isso não nos cause assombro. E por quê? Porque existe um sistema cuja voracidade não conhece limites. Esta civilização constantemente cria novas "necessidades" de consumo e, portanto, requer cada vez mais matériasprimas. O que constitui uma irracionalidade em si, pois criamos um modo de vida como se os recursos não tivessem fim, vivemos como se

\footnotetext{
${ }^{48}$ Conforme nos conta Monsalvo (2020), “Aleyne, em sua apresentação na I Assembleia Mundial de Saúde dos Povos em Savar, Bangladesh, disse ser de Aotearoa, que em idioma Maori significa: Terra da longa nuvem branca. Não vamos achar Aotearoa nos mapas, porque o conquistador impôs a este território o nome de Nova Zelândia”. Cartas que salen del Cuerpo. Carta 448. Disponível em: www.altaalegremia.com.ar. Acesso em 15 de nov. 2020.
} 
pudéssemos consumir infinitamente num planeta com "recursos naturais" finitos (ACOSTA, 2016a).

A iniciativa Yasuni-ITT gerou muitas adesões e visibilidade. No entanto, em que pese sua importância e transcendência simbólica, representa apenas uma pequena parte da Amazônia Equatoriana. Não se pode desconsiderar a intensa apropriação de "recursos naturais" (ecocídio) nesta região que há mais de 40 anos sofre com a exploração petroleira e que anteriormente sofreu com a extração ilegal da borracha e da madeira, de peles e também com a ampliação da fronteira agrícola.

Neste sentido, a proposta da Iniciativa Yasuni-ITT, ainda que de forma bastante modesta, poderia expressar uma nova relação com a Mãe Terra. Não explorar estes campos de petróleo permitiria-nos pensar para além da relação de expropriação da "natureza", chamando a atenção para a mudança climática, para a destruição de regiões biodiversas e de povos de recente contato e em isolamento. Tem um efeito demonstrativo de que necessitamos estabelecer urgentemente uma forma respeitosa de reciprocidade, de solidariedade e cuidado com a "natureza", porque isso representa nada mais nada menos que a possibilidade de continuidade da vida, principalmente a humana, no planeta. Parece-nos urgente refletir sobre os limites do planeta Terra para suportar a exploração imposta, sobretudo, nos últimos 500 anos de expansão deste padrão de poder do capital global.

Neste sentido, cremos ser importante reiterar nossa compreensão acerca do Sumak Kawsay/Buen Vivir. Muito embora, parte dos estudiosos deste tema identifiquem-no como uma alternativa ao desenvolvimento (ACOSTA, 2009, 2011; HIDALGO-CAPITAN, 2012; CUBILLO-GUEVARA, 2014), nossa perspectiva se relaciona com a declaração feita pelo Movimiento al Buen Vivir Global, a qual entende que o Sumak Kawsay/Buen vivir é um sistema sócio-político-espiritual:

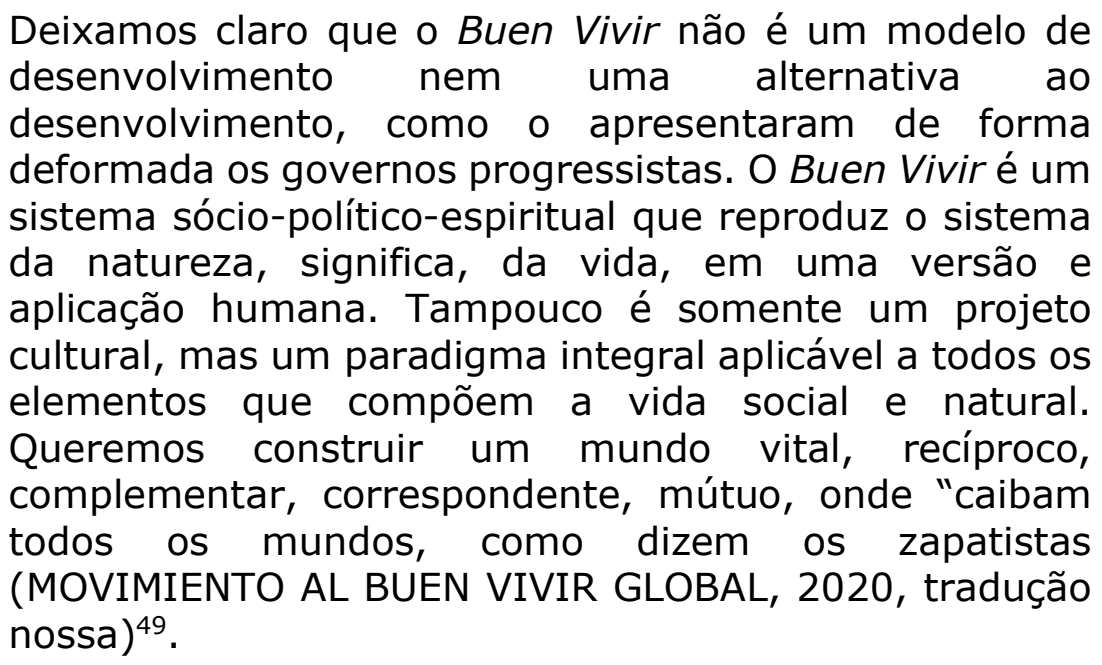

Em nosso entendimento, o Buen Vivir não propõe uma volta a um passado idílico, a uma vida pré-capitalista, como referiram intelectuais como Hidalgo-Capitan (2012) e Viola Recasens (2014). A proposta deste

\footnotetext{
${ }^{49}$ Disponível em < https://www.facebook.com/groups/770540906839242> Acesso em 02 de nov. 2020.
} 
Espaço Ameríndio

sistema sócio-político-espiritual pode ser entendida e construída na medida em que compreendemos os sentires/viveres encarnados nesta cosmovisão. Para isso, no entanto, é necessário abandonar o projeto civilizatório eurocêntrico, descartando, assim, parte dos cânones da ciência hegemônica ou padrão. 
Espaço Ameríndio

\section{Referências bibliográficas}

ACOSTA, Alberto. La maldición de la abundancia. Quito: Ed. Swissaid y Abya-Yala. 2009.

ACOSTA, Alberto. Solo imaginando otros mundos, se cambiara éste: Reflexiones sobre el Buen Vivir. In: FARAH, I.; VASAPOLLO, L. (Orgs.). Vivir bien: paradigma no capitalista? CIDES-UMSA, 1. ed. La Paz, Bolivia: Ed. Plural, 2011.

ACOSTA, Alberto. O bem viver: uma oportunidade para imaginar outros mundos. São Paulo: Autonomia Literária; Elefante. 2016a. 264 p.

ACOSTA, Alberto. Extrativismo e neoextrativismo; duas faces da mesma maldição. In: DILGER, Gerhar; LANG, Miriam; FILHO, Jorge Pereira (Orgs.). Descolonizar o imaginário: debates sobre pós-extrativismo e alternativas ao desenvolvimento. São Paulo: Fundação Rosa Luxemburgo, 2016b.

ARCINIEGAS, P. A.; SCHUBERT, J. Democracia Participativa dos Indígenas do Equador: dilemas entre o "Buen Vivir" e o desenvolvimentismo. 2015. Disponível em: http://www.ufrgs.br/sicp/files/2015/09/12_ARCINIEGAS-SCHUBERT.DemocraciaParticipativa-dos-Indi $\% \mathrm{C} 2 \% \mathrm{~A} 6 \% \mathrm{C} 3 \% \mathrm{BC}$ genas-do-Equador_dilemas-entre-o$\% \mathrm{C} 3 \% 94 \% \mathrm{C} 3 \% 87 \% \mathrm{C} 2 \% \mathrm{~A} 3 \mathrm{Buen}-\mathrm{Vivir} \% \mathrm{C} 3 \% 94 \% \mathrm{C3} \% 87 \% \mathrm{C3} \% 98$-e-odesenvolvimentismo.pdf Acesso em: 12 out. 2015.

CHOQUEHUANCA, D. Discurso de David Choquehuanca en toma de posesión como vicepresidente de 2020 Bolivia. Disponível em: https://www.youtube.com/watch?v=Dp8JMY4GssM. Acesso em: 8 nov. 2020.

DE LA TORRE. S. E.; MORAES. M.C. Sentipensar: Fundamentos e Estratégias Para Reencantar a Educação. Ed. Wak. 2018. 200 p.

DUQUE. C. A. A. La ampliación ontológico-política del Buen Vivir/Vivir Bien como praxis transmoderna: a expansão ontológico-política do Bem Viver/Viver Bem como uma prática transmoderna. Tese (doutorado) 2019. Universidade Estadual de Campinas/Instituto De Filosofia E Ciências Humanas. 2019.

DUSSEL, E. Política de la Liberación. Historia mundial y crítica. Colección Estructuras y Procesos Serie Filosofía. Madrid, Espanha: Editorial Trotto. 2007.

DUSSEL, E. 14 Tesis de ética Hacia la esencia del pensamiento crítico. Colección Estructuras y Procesos, Serie Filosofía. Madri, Espanha: Ed. Trotta. 2016.

EQUADOR. Decreto Presidencial No. 552, publicado en el Suplemento del Registro Oficial No. 121 del 2 de febrero de 1999. Disponível em: http://yasunitransparente.ambiente.gob.ec/documents/348542/351074/1999+Creación+ Zona+Intangible.pdf/61bafc5c-8cdf-4f57-be25-

981aadc9463b;jsessionid=xy7kLowckmJevzc-ttz25W+B. Acesso em: 3 out. 2016.

EQUADOR. Constituição do Estado Plurinacional do Equador de 19 de julho, Assembleia Constituinte, Quito. 2008. Disponível em: 
Espaço Ameríndio

http://www.asambleanacional.gov.ec/documentos/Constitucion-2008.pdf/. Acesso em 05 ago. de 2018.

ESCOBAR, A. Más allá del Tercer Mundo, globalización y diferencia. Bogotá, Colombia: Ed. Imprenta Nacional. 2005.

GARCIA LINERA, A. Disponível em: https://revistacrisis.com.ar/notas/bolivia-notiene-escrito-su-

destino?fbclid=IwAR0sIRkdW4erC5aso3zPWxXtH7b6ClplsebQ1R1eERdZ-Xog3u8XttO524. Acesso em 30 de out. 2020.

GROSFOGUEL, R. Del extractivismo económico al extractivismo epistémico y ontológico, Revista Internacional de Comunicación y Desarrollo, n. 4, p. 33-45, 2016.

GUDYNAS, E. Posextrativismo y alternativas ao Desarrallo desde la sociedade civil. In: LANG, M.; LOPES, C.; SANTILLANA, M. (Comps.). Alternativas al capitalismo/colonialismo del siglo XXI. 2. ed. Ciudad autônoma de Buenos Aires: América Libre, 2013.

HIDALGO-CAPITÁN, A. L. El Buen Vivir. La (re)creación del pensamiento del PYDLOS. Cuenca: Ed. PYDLOS, 2012.

HIDALGO-CAPITÁN, A. L.; CUBILLO-GUEVARA, A. P. Seis debates abiertos sobre el sumak kawsay. Íconos - Revista de Ciencias Sociales, n. 48, p. 25-40, feb. 2014. Disponível em: $\quad<$ http://revistas.flacsoandes.edu.ec/iconos/article/view/1204/1103 $>$. Acesso em 14 sep. 2016.

HUANACUNI MAMANI, F. Vivir Bien / Buen Vivir: Filosofia, Politicas, estrategias y experiencias regionales. La Paz, Bolivia: Ed. Prisa. Ed. 4. 2010.

LANDER, E. Com o tempo contado. Crise civilizatória, limites do planeta, ataques à dmocracia e povos em resistência. In: DILGER, G; LANG, M. FILHOS, J. P. (Orgs.). Descolonizar o imaginário: Debates sobre pós-extrativismo e alternativas ao desenvolvimento. São Paulo: Fundação Rosa Luxemburgo, 2016.

LARREA, C. ¿Petróleo o conservación en el Yasuní? Un dilema histórico para el Ecuador. Conferencia FLACSO. Quito. 2007.

LE QUANG, M. Dejar el Petróleo bajo Tierra. 1 ed. Quito, Equador: Ed. Iaen, 2013.

LE QUANG, M. VERCOUTÉRE, T. Ecosocialismo y Buen Vivir: Diálogo entre dos alternativos al capitalismo. 1 ed. Quito, Equador: Editorial IAEN, 2013. 92 p.

LO BRUTTO, G.; VAZQUEZ SALAZAR, Carlos Otto. ¿Buen vivir o desarrollo? Buscando alternativas y horizontes. Tla-melaua, v. 8, n. 37, p. 50-68. Puebla, México. 2015. em: http://www.scielo.org.mx/scielo.php?script=sci_arttext\&pid=S187069162015000100050\&lng=es\&nrm=iso. Acesso em: 07 ago. 2019. 
Espaço Ameríndio

LÓPEZ ABAD, Joaquín. La consulta libre, previa e informada en el Ecuador. Quito: Centro de Derechos Económicos y Sociales - CDES, 2016. 56p.

MARAÑÓN. B. P. Buen vivir y descolonialidad: crítica al desarrollo y la racionalidad instrumentales. 1. Ed. México: UNAM, Instituto de Investigaciones Económicas, 2014.

MOVIMIENTO AL BUEN VIVIR GLOBAL. Declaración. 2020. Disponível em < https://www.facebook.com/groups/770540906839242> Acesso em 02 de nov. 2020.

ORTIZ Ocaña, A. Decolonizar la Educación: Pedagogía, Currículo y Didáctica decoloniales. Barcelona: Editorial Academia Española. 2017a.

ORTIZ Ocaña, A. Decolonizar la investigación en educación. Praxis, n. 13, v. 1, p. 93104. $2017 \mathrm{~b}$.

ORTIZ Ocaña, A. Decolonizar las Ciencias Sociales: hacia una investigación decolonizante. Barcelona: Editorial Academia Española. 2017c.

ORTIZ Ocaña, A.; ARIAS López, M. I.; Hacer decolonial: desobedecer a la metodología de investigación. Hallazgos, n. 16, v. 31, p. 149-168. 2019.

ORTIZ Ocaña, A.; ARIAS López, M. I.; PEDROZO Conedo, Z. E. Decolonialidad de la Educación: Urgencia/emergencia de una Pedagogía Decolonial. Santa Marta: Universidad del Magdalena. 2018a.

ORTIZ Ocaña, A.; ARIAS López, M. I.; PEDROZO Conedo, Z. E. Metodología “otra” en la investigación social, humana y educativa: el hacer decolonial como proceso decolonizante. Revista FAIA, n. 7, v. 30, p. 172-200. 2018 b.

QUIJANO, A "Bien Vivir” para redistribuir el poder. Yachaykina. N. 13, Quito: ICCI, 2010.

QUIJANO, A.; WALLERSTEIN, I. La Americanidad como Concepto, o América en el Moderno Sistema Mundial. Revista Internacional de Ciencias Sociales, n. 3, v. 44, p. 583-591. 1992.

QUINTERO, P. Alternativas descoloniales al capitalismo colonial. 1. ed. Ciudad Autonóma de Buenos Aires: Del Signo, 2015.

RADOMSKY, G. Desenvolvimento, pós-estruturalismo e pós-desenvolvimento: a crítica da modernidade e a emergência de modernidades alternativas. Revista Brasileira de Ciências Sociais, v. 26, n. 75, fev. 2011.

RAMIREZ, R. La vida (buena) como riqueza de los pueblos: hacia una socioecologia política del tiempo. Quito: IAEN-INEC. 2012.

VIOLA RECASENS, A. «Discursos "pachamamistas" versus políticas desarrollistas: el debate sobre el sumak kawsay en los Andes», Iconos, n. 48, p. 64, 2014. 
Recebido em: 19/08/2021 * Aprovado em: 10/11/2021 * Publicado em: 23/12/2021 